\title{
THE DISTRIBUTION AND ZOOGEOGRAPHY OF FRESHWATER OSTRACODA (CRUSTACEA) IN THE WEST INDIES, WITH EMPHASIS ON SPECIES INHABITING WELLS
}

\author{
by
}

\author{
NICO W. BROODBAKKER
}

Institute of Taxonomic Zoology, University of Amsterdam, P.O. Box 20125, 1000 HC Amsterdam, The Netherlands

\section{SUMMARY}

The distribution of freshwater Ostracoda in the islands of the West Indies and part of the Venezuelan mainland is discussed. The ostracod fauna of wells and epigean habitats is compared. Some species, e.g. Cypretta spp. are found significantly more often in wells, others are only found in epigean habitats, e.g. Hemicypris spp. and Cypris subglobosa. Some species are found significantly more often in epigean habitats, e.g. Stenocypris major, others seem to have no preference, e.g. Physocypria affinis and $C_{y}$ pridopsis spp.

Joint occurrence of Ostracoda and other faunal groups in wells is studied, especially for hadziid amphipods, which are supposed to predate on small crustaceans. There may be some influence of the presence of hadziid amphipods on the distribution of some species of Ostracoda, but this could not be tested statistically for most islands and species.

Some biogeographical models are discussed. Most ostracods seem to have arrived at the islands by dispersal. No ostracods were found representing evidence for the regression model of distribution and speciation. Practically all species seem to be genetically stable and did not evolve into true hypogean species. Only in the presumably older islands Hispaniola and Cuba, true hypogean species are found, which seem to have evolved from relict freshwater ancestors.

The results strengthen the hypothesis that Cuba and Hispaniola have been part of a proto-Antillean arc, which has been connected with Yucatan. The fact that no hypogean species were found in the Lesser Antilles strengthens the hypothesis that these islands have emerged above the sea level independently of the Proto-Antilles and much later in time.

* Report 37 is published in the same issue of this journal.

\section{RÉSUMÉ}

On discute la distribution des Ostracodes dulcicoles sur les îles des Indes Occidentales et dans certaines zones de Venezuela. La faune d'Ostracodes des puits et des habitats épigés est comparée. Certaines espèces (par exemple des espèces de Cypretta) sont trouvées nettement plus souvent dans des puits, d'autres (par exemples Hemicypris spp. et Cypris subglobosa) sont rencontrées seulement dans des habitats épigés. Ensuite, il y a des espèces nettement plus souvent trouvées dans les habitats épigés (Stenocypris major par exemple), tandis que d'autres (exemples: Physocypria affinis et Cypridopsis spp.) ne semblent pas avoir de préférence.

On examine la présence dans les puits, conjointement à celle des Ostracodes, d'autres groupes d'animaux, surtout des Amphipodes Hadziides, dont on suppose que ce sont des prédateurs au dépens de petits Crustacés. Il est possible qu'il y ait une certaine influence de la présence de ces Amphipodes sur la distribution de certaines espèces d'Ostracodes, mais, pour la plupart des îles et des espèces, ceci n'a pas pu être mis en évidence sur des bases statistiques.

Des modèles biogéographiques différents sont discutés. La plupart des Ostracodes semblent avoir abordé les îles par dispersion. Des Ostracodes représentant des preuves pour le "modèle de régression" ne sont pas connus des Caraỉbes. Pratiquement toutes les espèces semblent être génétiquement stables et n'ont pas évolué pour donner de vraies formes hypogées. Des espèces effectivement hypogées n'ont été découvertes que sur Hispaniola et Cuba, îles supposées plus anciennes; ces espèces semblent avoir évolué à partir d'ancêtres dulcicoles relictes.

Les résultats obtenus viennent à l'appui de l'hypothèse que Hispaniola et Cuba ont fait partie d'un arc protoAntillais ayant été relié au Yucatan. Le fait que les Petites Antilles n'ont pas fourni des espèces hypogées, est un argument en faveur de l'hypothèse que l'émergence de ces îles a été indépendente et de beaucoup postérieure à celle des Proto-Antilles. 


\section{INTRODUCTION}

In the period 1973-1982 the Amsterdam Expeditions have made groundwater explorations in 43 West Indian islands and part of the Venezuelan mainland. Most of the stations sampled were wells, since these form the way of access to the subterranean fauna, especially in karstified sediments. A great number of hypogean animals were encountered, but also many epigean animals. The predominant groups were Oligochaeta, Gastropoda and four crustacean taxa: Ostracoda, cyclopoid Copepoda, Amphipoda, and Thermosbaenacea (Stock, 1983a). The ostracods were considered to be important because of their abundance and constancy in hypogean habitats, being present in more than half of the stations sampled, often in large numbers. They can also be part of the hypogean food chain, being a possible prey for larger hypogean amphipods (Stock, 1983a). Furthermore, the ostracods were thought to be usable for biogeographic modelling, since their distribution was thought to be influenced predominantly by dispersal, though some species could have originated by regression of marine ancestors or vicariant events. The different biogeographic models and their usefulness are discussed for ostracods in this article.

During this study it became clear that most of the ostracods encountered belong to epigean groups. This is caused by the fact that in karstified sediments, as encountered in tropical and subtropical regions, wells with a large diameter represent a habitat differing from the surrounding subterranean area (Danielopol, 1981). These wells play an important role for aquatic life; because of the dry seasons or dry climats in these regions, and the lack of other aquatic habitats, they provide some ecological stability. Only shallow open wells dry out during part of the year, like most shallow pools and ponds.

A well can be regarded in several ways:

(1) As a place where some epigean faunal elements can survive and perhaps even penetrate deeper in the true groundwater en- vironment and-adapt to real subterranean conditions.

(2) As a place where typical groundwater organisms can emerge from the surrounding groundwater system, and perhaps even survive.

(3) To study ecological processes, like the influence of restricted space, water volume, light conditions and other environmental factors, on the animals, and on the competition between them.

(4) As a place allowing observations on what happens when epigean species come in contact with groundwater species.

Wells are like islands which can be colonized, often by epigean, cosmopolitan species. The questions are whether colonization is common, whether many species succeed, which species are better colonizers, and whether it is possible for some species to adapt to the groundwater environment. Furthermore, the differences in composition and diversity of populations can be studied.

It became clear that only in the islands Hispaniola and Cuba some species (belonging to the genera Neocypridopsis and Strandesia) are present, which are possibly in some way adapted to live in groundwater environments, on account of their very small size, or reduced eye pigment. The same islands harbour other species, all belonging to the new genus Caribecandona of the subfamily Candoninae, which are stygobiont (Broodbakker, 1983c). In a well in the mainland of Venezuela another hypogean species was found, belonging to the new genus Danielocandona (Broodbakker, 1983c).

Therefore it became inevitable to study mostly the aspects (3) and (4). Since most species were supposed to be epigean, it was necessary to obtain samples from epigean habitats for comparison. Dr. P. Wagenaar Hummelinck kindly provided about 600 ostracod samples from mostly epigean habitats, sampled predominantly in the Lesser Antilles, between 1930 and 1973. He sampled many stations several times in different months or even years, especially on the islands Curaçao, Bonaire, Aruba and St. Martin. 
Furthermore, I received through Dr. D. L. Danielopol 37 ostracod samples from Cuba, mostly from caves, but also a few from pools and the underflow of running waters, sampled by Drs. L. Botosaneanu, St. Negrea and T. Orghidan, members of the Cubano-Romanian Biospeleological Expeditions to Cuba, in 1969, 1970 and 1973.

Only few papers have been published concerning the freshwater ostracods of the West Indies. Brady (1902) described Cypretta sarsi from St. Thomas, Sharpe (1910) described Chlamydotheca barbadensis from Barbados, and Brehm (1949) described some species, viz. Cypretta margalefi, Cytheridella ilosvayi Von Daday, 1905 and Stenocypris major (Baird, 1859), from Cuba. Most other species have been described by Klie (1933) and Triebel $(1961,1962)$ from stations sampled by Dr. P. Wagenaar Hummelinck. Margalef (1961) described some species from the Venezuelan island of Margarita, which proved to be already described by Klie (1933) from Bonaire and Aruba. Van den Bold (1958) mentioned some species from rivers in Trinidad, which he thought to be identical with European species. Harrison \& Rankin (1976), in a hydrobiological study of St. Vincent, reported a number of species from this island, which were in part wrongly identified.

During my research it became clear that many species had not yet been described, which meant that a great part of my research had to consist of a taxonomic analysis of a few freshwater ostracod genera, and of the partly hypogean subfamily Candoninae. It appeared necessary to describe both the carapace and the limbs as precise as possible. In order to describe the chaetotaxy, Dr. Danielopol and I designed a descriptive system (Broodbakker \& Danielopol, 1982). Furthermore, the ecology of species belonging to the chosen groups was studied, differences between populations of different habitats and islands, especially in carapace length, were examined, and the geographical distribution of these and related species was discussed. This was done for the species of the genus Heterocypris (Broodbakker, 1982, 1983a), of the genus Hemicypris (Broodbakker, 1983b), of the genus Strandesia (Broodbakker, 1983d, 1984a), of the subfamily Candoninae (Broodbakker, 1983c), and for the species Tanycypris meridana (Furtos, 1936) (Broodbakker, 1984b). Other genera, like Cypretta and Cypridopsis, could not be studied because of the lack of good descriptions and of time.

In the present paper the distribution of all freshwater ostracods, on all islands sampled, is recorded and discussed. The ostracod fauna of wells is discussed and compared with that of epigean habitats. This is done since most of the habitats sampled were either wells or stagnant epigean habitats. Roughly $50 \%$ of the samples taken in both types of habitat, being 360 wells, and 182 stagnant epigean habitats, yielded Ostracoda. Only 37 caves, of which 24 in Cuba, yielded Ostracoda, while only few caves have been sampled in the other islands.

Furthermore, the effect of the presence of hypogean amphipods, in particular Metaniphargus, is studied. Finally, the different zoogeographical models are discussed in connection with the distribution of the freshwater ostracods in the West Indian islands.

\section{MATERIAL AND METHODS}

Information concerning the samples is provided in table I, in Stock (1979), Wagenaar Hummelinck (1940a-b, 1953 * 1981) (abbreviated as $S$ and $W H$ in the sequel) and in my previous papers concerning the Ostracoda of the West Indies.

Computer sorted data on habitat, light conditions, water table, water depth and the abundance of accompanying fauna, were statistically compared with the presence of the different ostracod species by way of $G$-tests.

The G-test. - Instead of chi-square tests, $G$-tests were performed, because the $G$-test has a theoretical advantage over the former, and is computationally simpler (Sokal * Rohlf, 1981: 704). Critical values for the $G$-test can be found in a chi-square table, since the distribution of $G$ approximates the chi-square distribution. The tests are onetailed since only large values of $G$ are used for rejecting the hypothesis that there is no influence of the factor in question. $G$ was computed for frequency distributions arranged by a single criterion of classification. Frequency distributions for all dominant species were calculated for grouped islands and classes of environmental factors, or types of accompanying fauna. 
Expected frequencies were calculated by multiplying the number of samples containing ostracods in each type or class $\left(n_{t}\right)$ with the total number of samples yielding the ostracod in question $\left(n_{1}\right)$, divided by the total number of samples yielding ostracods in the respective island group or island $\left(n_{2}\right)$, which is illustrated in table III. So:

$$
F_{\mathrm{e}}=\frac{n_{\mathrm{t}} \cdot n_{1}}{n_{2}}
$$

Only when all expected frequencies are larger than 5 , it is permitted to calculate a $G$-value. Whenever a $G$-value was significantly large, it was adjusted by applying Williams' correction (q) (Sokal * Rohlf, 1981: 705):

$$
\begin{aligned}
& q=1+\frac{\nu+2}{6 n_{1}}(\nu=\text { degrees of freedom }) \\
& G_{\text {adj }}=\frac{G}{q}
\end{aligned}
$$

Data were sorted with the CDC computer of SARA (Stichting Academisch Rekencentrum Amsterdam). $G$-tests were performed with a Sinclair ZX-spectrum home computer.

\section{DISTRIBUTION OF THE SPECIES}

In this chapter the ostracod fauna of every sampled island group and the mainland of
Venezuela is described and discussed separately. The criteria for grouping the islands were either short mutual distance, proximity to the mainland, or a position on the same bank.

All islands sampled are listed in table I and shown in fig. 1. In the table many of the species encountered in the West Indies are listed, except for species which were only found in one or two islands, for species of Darwinula, and for Perissocytheridea cribrosa (Klie, 1933). The species that are not listed are discussed in the text. In the right part of table I the total number of fresh- and brackish-water stations that have been sampled by the Amsterdam Expeditions and the expeditions of Dr. Wagenaar Hummelinck are listed separately. The combined number of samples yielding ostracods is given, as well as the number of samples from each of the listed habitats that yielded ostracods.

\section{MAINLAND OF VENEZUELA}

(Table I: nrs. 1, 2)

Part of the Estado Falcón was sampled extensively in 1982 by the Amsterdam Expeditions,

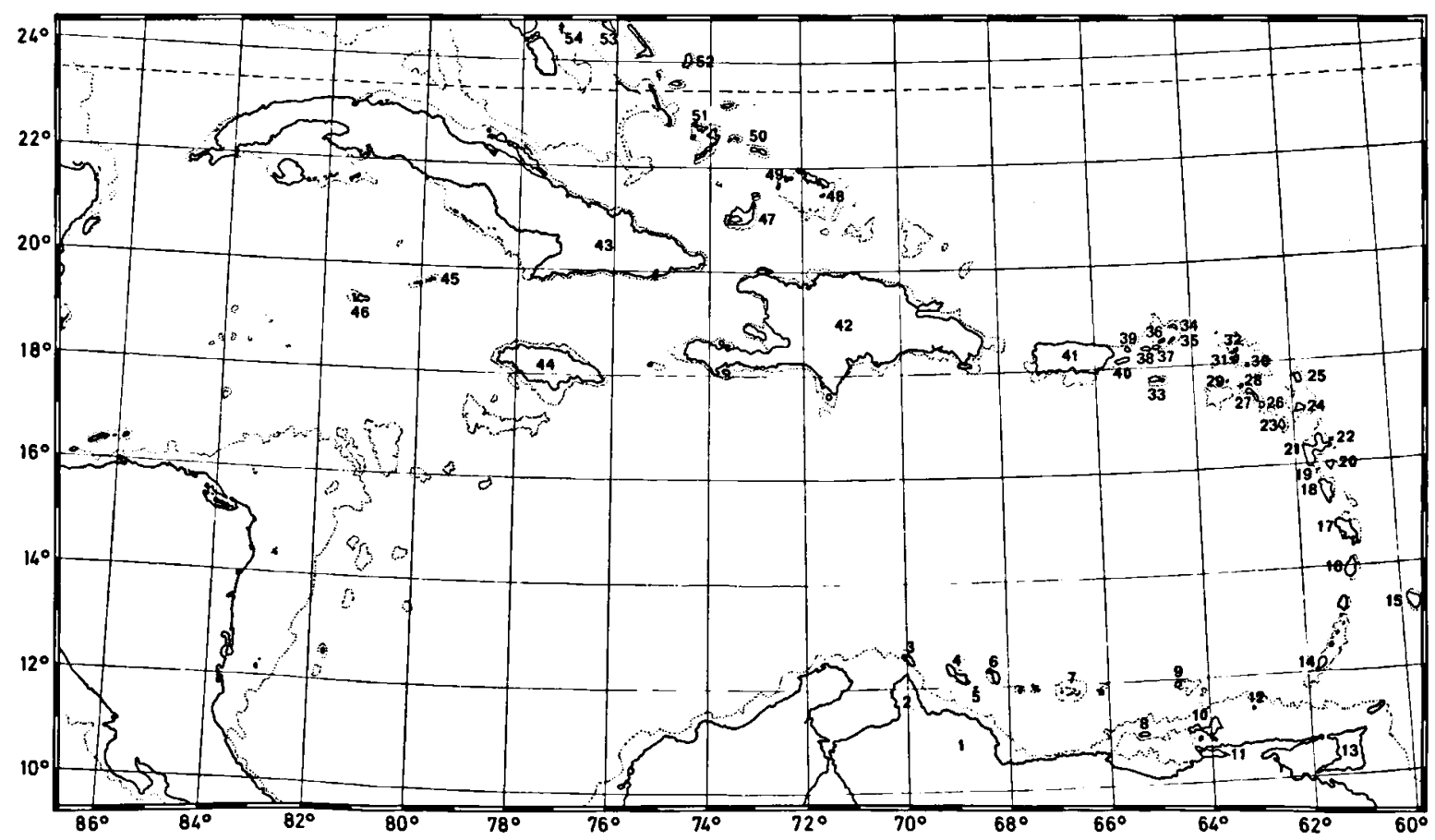

Fig. 1. Map of the Caribbean, showing (dotted) the $200 \mathrm{~m}$ line being the edge of the continental shelf. The numbers of the islands and regions correspond with those given in table I. 
especially the Sierra de San Luis, a calcareous chain of mountains, and the Peninsula de Morocoy, a karst region with many cenotes. One species, Strandesia venezolana Broodbakker, $1983 \mathrm{~d}$, is very common, especially in the cenotes, but it was also found in the underflow of running waters in this state and in a river 50 $\mathrm{km}$ south of Caracas (Broodbakker, 1983d). It was once encountered in a cave. Pseudocandona aff. antilliana, Ps. geratsi and Candonopsis hummelincki were found in the underflow of running waters in the Estado Falcón, but also in other states of Venezuela, as Sucre and Aragua. All these candonid species are described and discussed in Broodbakker (1983c). C. hummelincki was also found in the underflow of running waters in the Distrito Federal.

Cypretta sp., Darwinula sp. and Physocypria sp. were found in some cenotes and springs of the Estado Falcón. In one muddy pool and a very shallow, muddy spring, specimens of Chlamydotheca aff. arcuata (Sars, 1901) were found, once together with Physocypria sp.

The districts of Falcón sampled in 1982 are relatively humid and rich in vegetation. In the arid Peninsula de Paraguana, which is part of the Estado Falcón, species like Chl. aff. arcuata and $S$. venezolana were not found. The ostracod fauna of this peninsula, which was sampled by the Amsterdam Expeditions in 1978 and by Dr. P. Wagenaar Hummelinck in 1937, shows more affinities with that of the arid islands off the coast, and with that of the partly arid peninsula de Araya, a coastal district opposite the Isla Margarita. In only four out of twelve wells sampled in Paraguana, ostracods were found. In three of these wells Cypretta sp. was found, and two of them also yielded Heterocypris margaritae Margalef, 1961, while the fourth well yielded three specimens of Chlamydotheca barbadensis Sharpe, 1910 (see discussion on its taxonomy below).

In a well in Calabozo, a town $150 \mathrm{~km}$ south of Caracas in the Estado Guárico, a new hypogean species of a new genus of the subfamily Candoninae was found, Danielocandona lieshoutae Broodbakker, 1983c. Furthermore, another probably hypogean species of a new genus belonging to the Cypridopsini was found in an interstitial sample from the Estado Sucre. This species will be described in a forthcoming paper.

\section{THE VENEZUELAN ISLANDS}

(Table I: nrs. 7 to 12 )

The Isla Margarita, which is situated on the continental shelf of Venezuela, presents twelve species of ostracods. One species, Rudjakoviella prolongata (Triebel, 1962) being the only known representative of the tribe Rudjakoviellini of the subfamily Cypridinae, was assumed to be endemic to Margarita. However, it was also found in a pool on the island Iguana of Los Testigos (WH 30). Triebel (1962) described it from a roadside pool on Margarita (WH 24). It appeared to be present in samples from the pools WH 18 and $\mathrm{S} 82 / 19$ as well.

Heterocypris margaritae Margalef, 1961, is the species most commonly found on Margarita. It was also found on the Venezuelan islands La Blanquilla, Los Testigos, and La Tortuga (Broodbakker, 1983a).

Triebel (1961) described Chlamydotheca hummelincki with two subspecies, hummelincki and dispar, from St. Eustatius (WH 507). During my research it became clear that this species has a wide distribution, being common in the Venezuelan islands, St. Eustatius, St. Martin and other Lesser Antilles, including Barbados. However, as early as 1910, Sharpe had described Chl. barbadensis from a small pond on Government Hill, Barbados. Triebel considered this to be a different species, because of minor differences in the description of the valves and maxillula. Since Sharpe's description is relatively poor, I consider the two species to be synonymous, especially since I found this species on Barbados, St. Eustatius, and in samples from many other islands. Therefore Chl. hummelincki becomes the junior synonym of Chl. barbadensis. The subspecies dispar, described by Triebel (1962) from St. Martin, and the subspecies nordestina described by Kotzian (1974) from Brazil, have to be ascribed to $C h l$. barbadensis. 


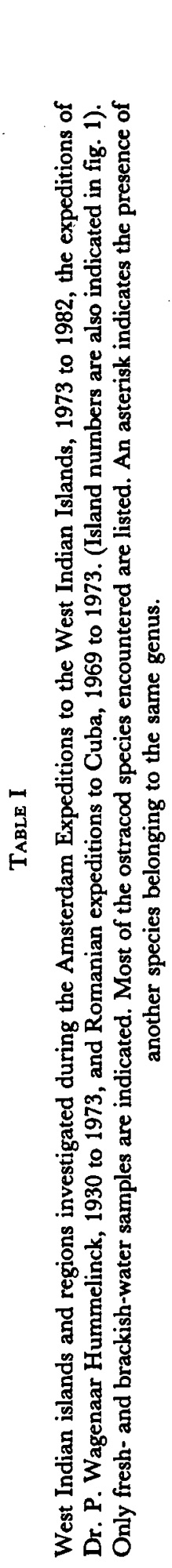

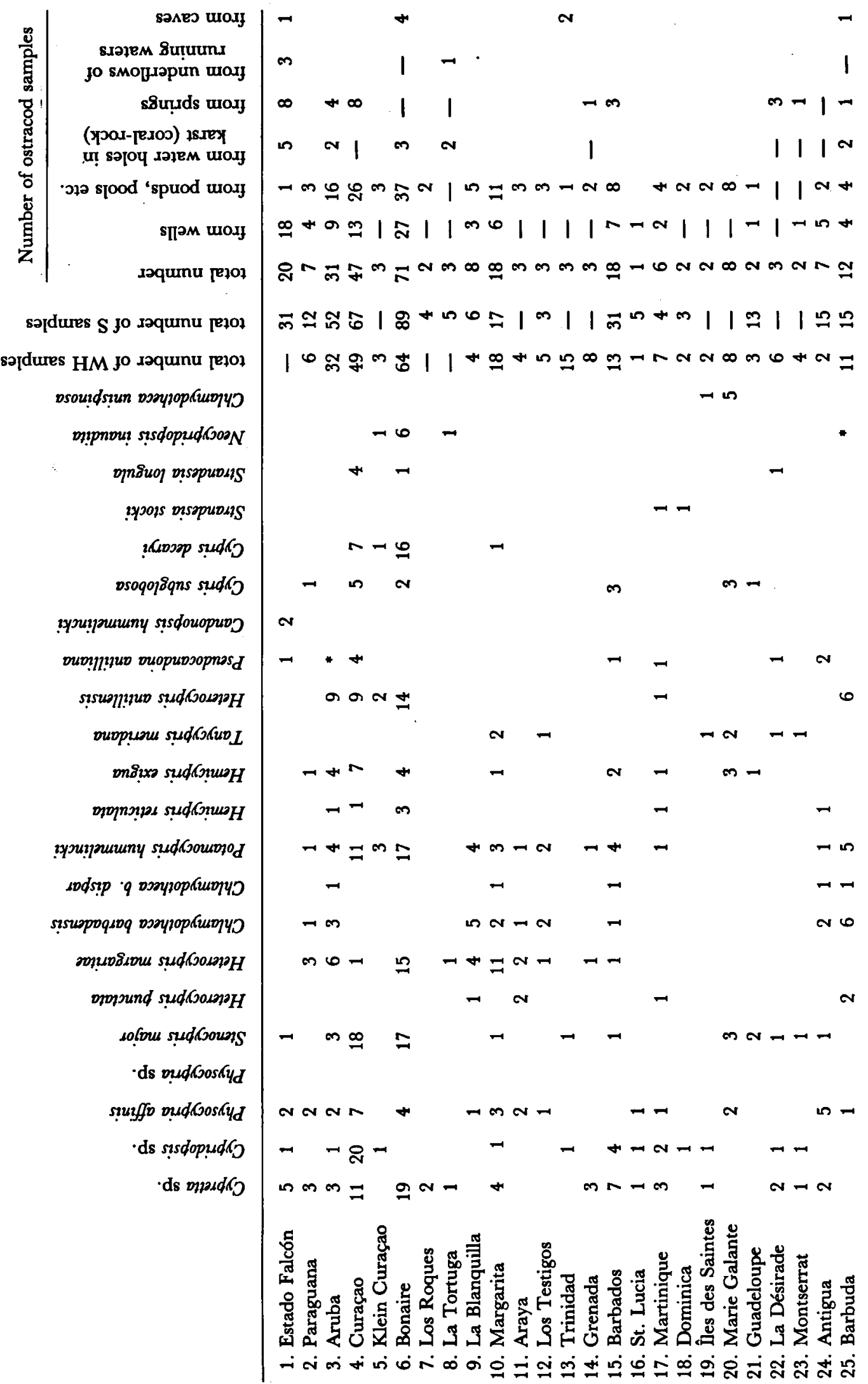


BIJDRAGEN TOT DE DIERKUNDE, 54 (1) - 1984

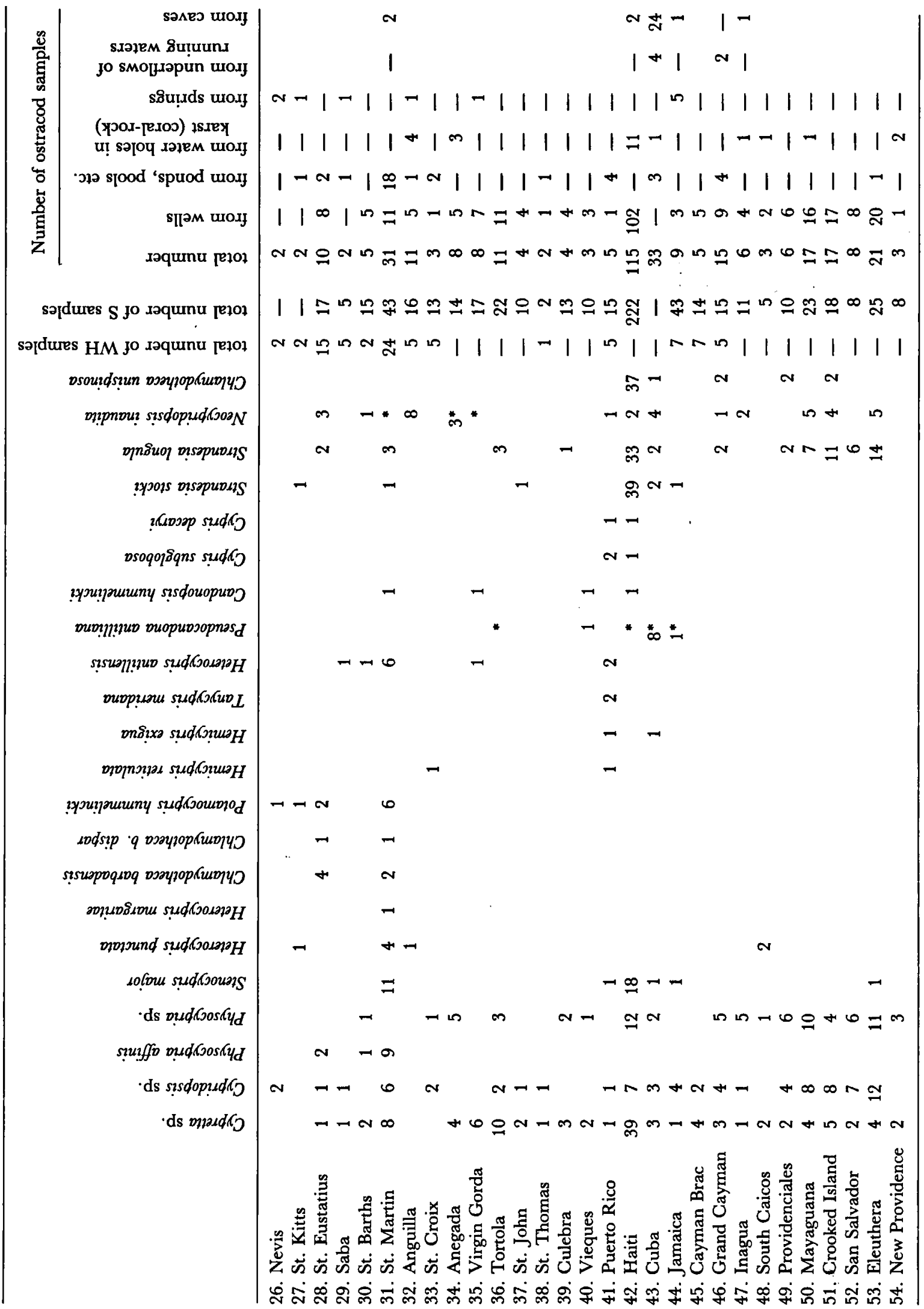


Other species which were found on Margarita as well as on La Blanquilla, Los Testigos, and Araya, are Physocypria affinis and Potamocypris hummelincki, both described by Klie (1933) from Bonaire and Aruba. The latter was erroneously considered by Margalef (1961) as a new species, $P$. ombrophila, from Margarita. Margalef also described Physocypria sanctaeannae from Margarita, a species different from $P$. affinis according to his drawings, which was, however, not encountered during this study.

Cypretta sp. was found on Margarita, La Tortuga, and as only species on Los Roques. Stenocypris major (Baird, 1859), Hemicypris exigua Broodbakker, 1983b, Cypris decaryi Gauthier, 1933, and Cypridopsis sp., were all found once on Margarita, but not on the other Venezuelan islands. Tanycypris meridana (Furtos, 1936) was encountered on Margarita and Los Testigos (Broodbakker, 1984b). Neocypridopsis inaudita (Furtos, 1936) was found in a hole with brackish water on La Tortuga, and Heterocypris punctata Keyser, 1975, in a small dug-out well on La Blanquilla (Broodbakker, 1983a).

It seems that the freshwater ostracod fauna of the Venezuelan islands is essentially the same as that of the nearby Netherlands Antilles, Aruba, Bonaire and Curaçao, Tanycypris meridana being the only species which was not encountered on one of these three islands. Isla Margarita presents most species, probably because on this island more stations were sampled than on the other islands, but also because there are much less freshwater habitats available on the other smaller islands. Fresh water is virtually absent on La Tortuga, which presents only some brackish-water habitats, and Los Roques, which presents only a few rainwater pools.

The best way to find out which species are essentially present on these small islands would be to raise ostracods from several samples of dried mud and from dried-in pools or borders of pools from each island.

ARUBA, BONAIRE, CURAÇAO

(Table I: nrs. 3 to 6 )

These islands have a comparable ostracod fauna. Bonaire, in which most samples were taken, presented most species, but in contrast to Margarita it is not the largest of these three islands, as it comprises only $60 \%$ of the size of Curaçao.

On Aruba, which is situated on the continental shelf of Venezuela, Heterocypris antillensis Broodbakker, 1982, and $H$. margaritae are the most common species. On Bonaire these species are also common, but on this island Cypretta sp., Stenocypris major, and Cypris decaryi, are common too. On Curaçao the same species are commonly found, except for $H$. margaritae, which was present in one sample only. However, on this island Cypridopsis sp. is the most common species, while it was not found on Bonaire, and only once on Aruba. Neocypridopsis inaudita was found on Bonaire only, and once on Klein Curaçao, a very small island $\left(1.2 \mathrm{~km}^{2}\right)$ between Curaçao and Bonaire.

The presence of Cypridopsis sp. in many samples of Curaçao, but not on Bonaire, is very peculiar, as is the almost complete absence of Heterocypris margaritae on Curaçao. Furthermore, the absence of Chlamydotheca barbadensis on Bonaire and Curaçao, and of Heterocypris antillensis on the Venezuelan islands, is striking.

Another strange phenomenon is the presence of a species resembling Chlamydotheca mexicana Sharpe, 1903, in pools on Klein Bonaire, a small island $\left(7 \mathrm{~km}^{2}\right) 750 \mathrm{~m}$ west of Bonaire. This species was found nowhere else in the Caribbean.

In many springs on Curaçao Darwinula cf. stevensoni (Brady \& Robertson, 1870), and/or Pseudocandona antilliana Broodbakker, 1983c, were found. On Bonaire $D$. cf. stevensoni was found in a spring, in several cave waters, and in a sink hole. On Aruba it was found once in a spring. In some other springs on Bonaire another unidentified species of Darwinula was found. Ps. antilliana was neither found on Bonaire nor on Aruba.

In many brackish-water habitats of all three islands Perissocytheridea cribrosa was found, a species described as Leptocythere by Klie (1933) from brackish waters on Bonaire, and redescribed by Keyser (1975) from brackish waters 
in southern Florida. This species was also present in brackish-water samples from St. Martin and Anguilla.

The ostracod fauna of Aruba, Bonaire and Curaçao is essentially the same as that of the Venezuelan islands and the arid parts of the continent, as was mentioned before. Since the Netherlands Antilles were sampled much more intensively than the other islands, more species were encountered. The absence or presence of some species in one or more of these islands can not be explained by any ecological factor measured. A way to find out if there are differences in species diversity and if some species are really absent, is to collect samples of dried mud in the islands and to raise ostracods from these mud samples.

\section{TRINIDAD}

\section{(Table I: nr. 13)}

From Trinidad only few ostracod samples are available. A few brackish-water samples contained Thalassocypridinae, a subterranean river yielded Darwinula cf. stevensoni and another Darwinula species, and a fish pond Stenocypris major and Cypridopsis sp.

Van den Bold (1958) studied ostracod carapaces collected in rivers on Trinidad. He mentions D. stevensoni, S. major, Cypridopsis cf. vidua (O. F. Müller, 1776), and Candona cf. fabaeformis Fischer, 1854, from the upper ranges of the rivers, more than $\mathbf{1 5} \mathrm{m}$ above sea level. Except for Candona these are the same species as found in the few stations sampled by Dr. P. Wagenaar Hummelinck on this island. Van den Bold found several other species in the slowly flowing to semi-stagnant waters in flat country, which he thought to be identical with European species, like: Ilyocypris cf. bradyi Sars, 1890; Cypria cf. exsculpta (Fischer, 1855); C. cf. ophthalmica (Jurine, 1820); Eucypris cf. ornata (O. F. Müller, 1776); and $E$. cf. lilljeborgi (G. W. Müller, 1900). In my opinion, most if not all of these species represent South American species which are not identical with the species mentioned above.

The other species discussed by Van den Bold are marine and brackish-water species.

\section{WINDWARD ISLANDS}

(Table I: nrs. 14 to 17 )

From the volcanic islands, Grenada, St. Lucia, and Martinique, only few samples are available. No stations have been sampled in The Grenadines and St. Vincent.

St. Vincent has been the subject of intensive hydrobiological investigations by Harrison \& Rankin (1976). They found several species of ostracods: Cypretta infesta Klie, 1943, Cypretta sarsi Brady, 1902, and Strandesia elliptica (Sars, 1901), in the stony parts of rivers; Cypridopsis vidua and Stenocypris sp., in permanent pools; moreover, all these species including Darwinula stevensoni, in marshes. In the marginal vegetation of a trophically rich, slowly flowing river they found large numbers of Stenocypris major, and in river pools near the sea Heterocypris symmetricus (G. W. Müller, 1898). In one rivulet Chlamydotheca unispinosa (Baird, 1862) was found.

However, the species determined by Harrison \& Rankin as Strandesia elliptica is most probably $S$. stocki, as is explained in Broodbakker (1983d); Heterocypris symmetricus is probably $H$. punctata, a mistake also made by Furtos (1936) for a specimen from Yucatan (Broodbakker, 1983a). Most Cypretta species will have to be restudied since the morphological characters of most of these are barely known. Sohn \& Kornicker (1973) wrote an excellent monograph on the genus, but they redescribed only some species. Victor \& Fernando (1981) redescribed and described eleven species from Malaysia, Indonesia and the Philippines. All species from the Neotropics are barely or poorly described, which is the most important reason why the Cypretta spp. encountered during this study could not be identified. Under these conditions, all species found by Harrison \& Rankin are most probably also found in the other Antillean islands.

The species that are present in the few samples from Grenada, St. Lucia and Martinique are also found in the other Antillean islands.

In Barbados many wells and some epigean stations were sampled. Only eight wells and 
most of the epigean habitats yielded ostracods. The species encountered are the same as those from the other Lesser Antilles, with the exception of Hemicypris barbadensis, a species endemic to Barbados, that strikingly resembles $H$. aurita (Klie, 1939) from the high mountains in Kenya. It is described in Broodbakker (1983b).

\section{LEEWARD ISLANDS}

(Table I: nrs. 18 to 40 )

\section{DOMINICA}

On Dominica only few stations have been sampled. Only two samples yielded ostracods. A slowly flowing streamlet yielded Cypridopsis aff. vidua and Strandesia stocki Broodbakker, 1983d, and a brackish ditch yielded a species of the subfamily Thalassocypridinae.

\section{GUADELOUPE, MARIE GALANTE,} ÎLES DES SAINTES, LA DÉSIRADE

(Table I: nrs. 19 to 22 )

On these islands some epigean stations have been sampled by Dr. Wagenaar Hummelinck, which yielded mostly the same species as the islands off the Venezuelan coast, but for a few exceptions. Chlamydotheca unispinosa (Baird, 1862) was found on Îles des Saintes, Marie Galante, and Guadeloupe. This species is common in Haiti, and is moreover found in St. Vincent, the Bahamas, Cuba, Jamaica, the Cayman Islands, southern U.S.A., and Yucatan, but not in the other Lesser Antilles. It seems to be represented by disjunct populations on the islands around Guadeloupe and on St. Vincent.

Marie Galante presented two species which are not, or rarely, found in the other islands: Strandesia trispinosa galantis Broodbakker, 1983d, a subspecies of $S$. trispinosa which was described by Pinto \& Purper (1965) from southern Brazil; and $S$. sphaeroidea Broodbakker, 1983d, which was found in several samples, and furthermore in only one sample from Antigua.

Tanycypris meridana was found on three of the islands of this group (table I).

The Amsterdam Expeditions collected 13 pump- or well samples on Guadeloupe, of which only one yielded one ostracod, a specimen of Stenocypris major. Only three epigean stations were sampled, of which one yielded S. major, Cypris subglobosa and Hemicypris exigua.

\section{MONTSERRAT}

(Table I: nr. 23)

On Montserrat only four epigean stations have been sampled, of which a pond harboured $S$. major, and a streamlet Cypridopsis aff. vidua, Cypretta sp., and Tanycypris meridana.

\section{ANTIGUA \& BARBUDA}

(Table I: nrs. 24 and 25)

Barbuda, a calcareous island, and Antigua, a partly volcanic and partly calcareous island, are situated on the same shelf fragment, just north of Guadeloupe. On Antigua only one pond, one basin and five wells yielded ostracods. All species, except for Strandesia sphaeroidea, have been found also in the islands off the Venezuelan coast.

On Barbuda only 2 out of 13 wells yielded ostracods, perhaps because of the presence of the large hypogean amphipod Metaniphargus, a situation which will be discussed in the sequel. In contrast, practically all epigean stations sampled yielded ostracods. All species encountered, except for Neocypridopsis debilis Klie, 1940 , have also been found in the islands off the Venezuelan coast. $N$. debilis was described from northeast Brazil, but was rediscovered in samples from Barbuda and St. Martin.

\section{NEVIS, ST. KITTS, ST. EUSTATIUS, SABA}

(Fig. 2; table I: nrs. 26 to 29)

Of these volcanic islands, the first three are situated on the same shallow bank (fig. 2). On Nevis and St. Kitts only four epigean stations have been sampled. All species, except for Strandesia stocki, are also found in the islands off the Venezuelan coast.

On St. Eustatius only 4 out of 17 wells yielded ostracods. Dr. Wagenaar Hummelinck sampled 11 uncovered pool-like wells and 4 cisterns, of which 8 yielded ostracods. All 
species encountered occur on the islands off the Venezuelan coast as well.

On Saba only few stations have been sampled. One pool harboured Cypridopsis species and Heterocypris antillensis, and a spring yielded Cypretta sp.

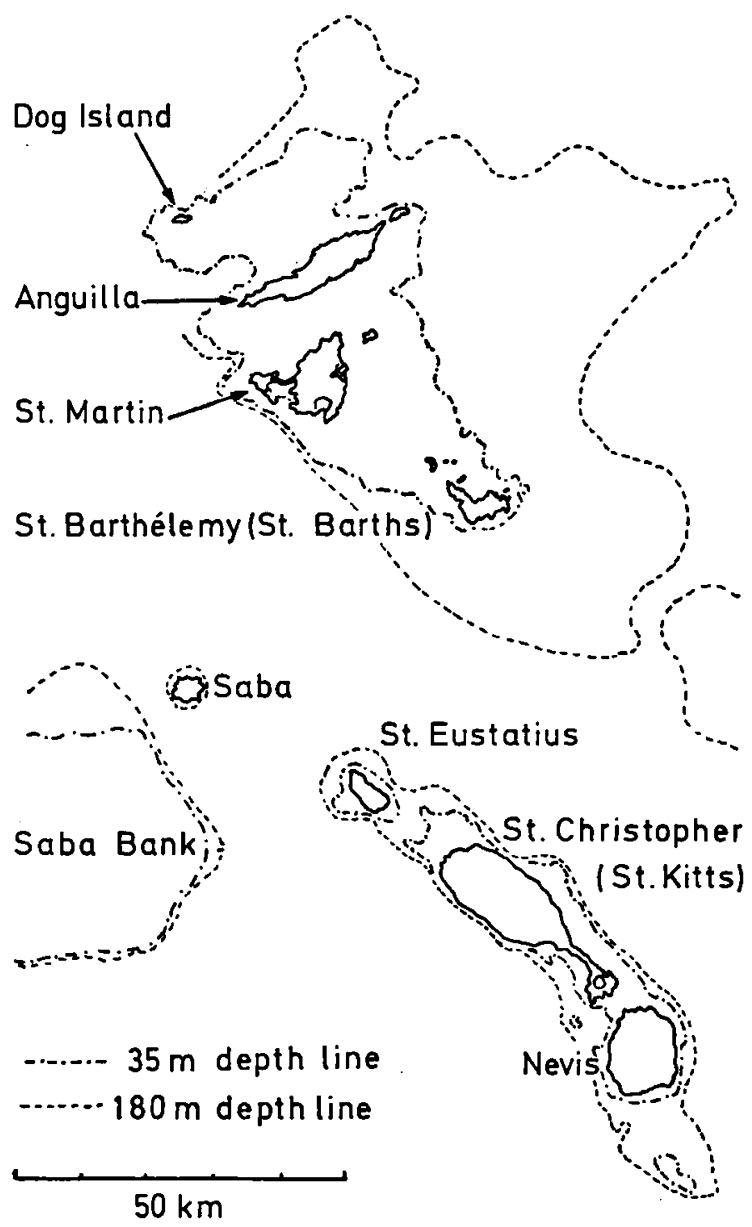

Fig. 2. Map of the islands on the shallow banks of St. Martin and St. Kitts, and the island Saba. Depth contour intervals of $35 \mathrm{~m}$ and $180 \mathrm{~m}$ are indicated (after U.S. Hydr. Off. Charts).

\section{ST. BARTHÉLEMY, ST. MARTIN, ANGUILLA}

(Fig. 2; table I: nrs. 30 to 32 )

Both St. Martin and St. Barthélemy are partly volcanic and partly calcareous; Anguilla is merely calcareous. All three islands are situated on the same shallow bank.

On St. Barthélemy only few wells, but no epigean stations, yielded ostracods. All species encountered are also found in the other islands of the Leeward Group.

On St. Martin many stations have been sampled, by the Amsterdam Expeditions as well as by Dr. Wagenaar Hummelinck. In brackish waters either Heterocypris punctata or Perissocytheridea cribrosa (Klie, 1933) were found. Stenocypris major, Potamocypris hummelincki, and Cypridopsis sp., were found in many pools, cisterns and open pool-like wells. Cypretta sp. was encountered in wells and pool-like wells, and Chlamydotheca barbadensis in a few cisterns. Heterocypris antillensis was found in three wells and three pools, $H$. margaritae in one pool, and Neocypridopsis debilis in a well and a trough. Strandesia longula was found in a well, a pool-like well and a pool, and $S$. stocki in a rock pool. The latter two Strandesia species are described in Broodbakker (1983d).

Mr. J. J. Jongsma sampled some dried mud for me in Slob of Welgelegen, a few $\mathrm{km}$ west of Philipsburg, on St. Martin. From this sample I have raised five species of ostracods: Stenocypris major Strandesia longula, S. stocki, Physocypria affinis and Neocypridopsis debilis. The fact that so many species could be raised in just a few weeks, from one sample of mud, seems to indicate that this is another way of getting some better idea of the ostracod fauna of the West Indian islands, especially since part of the species raised were present in only few of the stations sampled.

The ostracod fauna of St. Martin seems to be for the greater part the same as that of the islands off the Venezuelan coast, with a few exceptions: Hemicypris exigua, $H$. reticulata (Klie, 1930), Cypris decaryi, and C. subglobosa Sowerby, 1840 (all being epigean species, especially common in the Netherlands Antilles off the Venezuelan coast,' but also found in Puerto Rico). Both Cypris species were also found in Haiti. However, neither of these species was found on St. Martin. The only species which were not found in the islands off the Venezuelan coast are: Strandesia stocki, a species common in Haiti, which was also found in samples from Martinique, Dominica, St. Kitts and St. John, and probably St. Vincent (Brood- 


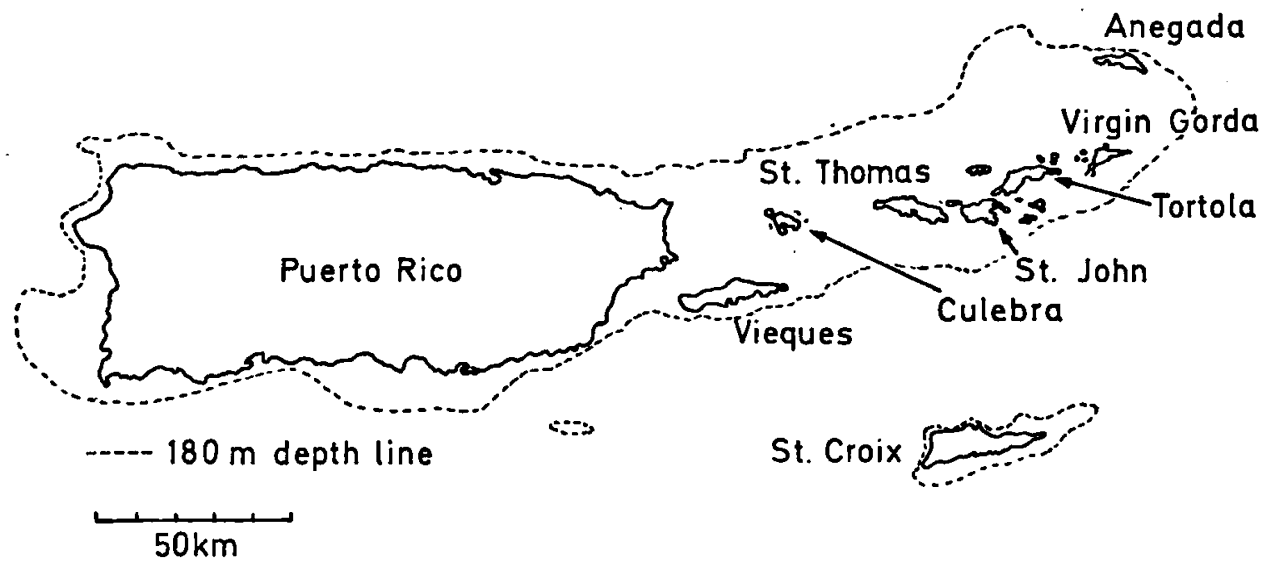

Fig. 3. Map of the Puerto Rico - Virgin Islands area. Depth contour interval of $180 \mathrm{~m}$ is indicated (after U.S. Hydr. Off. Charts).

bakker, 1983d); and Neocypridopsis debilis, which was also found in Barbuda, and was described by Klie (1940) from Brazil.

On Anguilla only few epigean stations have been sampled. A brackish puddle yielded Heterocypris punctata, while the mostly brackish wells yielded Neocypridopsis inaudita, Eucypris sp., Perissocytheridea cribrosa, and Thalassocypridinae. Darwinula sp. was found once.

On Dog Island, a small key just north of Anguilla, one well was sampled, which harboured Pseudocandona antilliana and Darwinula sp. (Broodbakker, 1983c).

\section{VIRGIN ISLANDS, ST. CROIX, PUERTO RICO}

(Fig. 3; table I: nrs. 33 to 41 )

Practically all stations sampled on the Virgin Islands were wells and rock crevices in karst areas. Dr. Wagenaar Hummelinck sampled some epigean stations on St. Croix and Puerto Rico, and one station on St. Thomas. Only few wells could be sampled by the Amsterdam Expeditions in Puerto Rico, because water works have been constructed, and most old wells have been filled up. Only one well in Puerto Rico yielded a damaged specimen of an ostracod. The few stations sampled by Dr. Wagenaar Hummelinck yielded relatively many species (table I). On St. Croix, which is separated from the remaining Virgin Islands by a deep trench (fig. 3), only one out of the 13 wells sampled yielded ostracods, belonging to Physocypria sp. Of the five pools sampled by Dr. P. Wagenaar Hummelinck, two yielded the species Hemicypris reticulata, Stenocypris major and Cypridopsis sp.

Cypretta sp. is the most common species in the wells of the Virgin Islands, followed by Physocypria sp. and Cypridopsis sp. (table I). Other species encountered are: Candonopsis hummelincki and Pseudocandona antilliana, both found once in very shallow pool-like wells on Vieques, Strandesia longula in a well on Culebra and in three wells on Tortola, and a specimen of a Pseudocandona species in a well on Tortola. On Virgin Gorda, Candonopsis hummelincki was found in an open well, Heterocypris antillensis in a shallow open well, and a hitherto undescribed species of Neocypridopsis, closely related to $N$. debilis, in a spring together with Darwinula sp. On Anegada the same species of Neocypridopsis was found in a well, and in three crevices in a karst area, together with Neocypridopsis inaudita.

Only few ostracod samples were available from each island. Many species were found only once in the mostly shallow, open pool-like wells sampled. It is therefore highly probable that these islands are much richer in species than is presently known. Except for St. Croix, all islands, including Puerto Rico, are situated 
on the same bank. It is highly probable that this bank emerged as a whole, at least only 7000 years ago. After this time the islands were separated because of a rising sea level (Pregill \& Olson, 1981). This could mean that all these islands potentially have the same ostracod fauna.

According to the available data, the ostracod fauna of the Virgin Islands, Puerto Rico and St. Croix could be essentially the same as that of the other Leeward Islands. No Chlamydotheca species have been found, but this may be due to the low number of epigean stations sampled, as is illustrated by the many species found in the few epigean samples from Puerto Rico and St. Croix. Only one species is specific to this island group, Neocypridopsis sp., a species closely related to $N$. debilis.

\section{HAITI (HISPANIOLA)}

(Table I: nr. 42)

In 1978 and 1979 the Amsterdam Expeditions sampled about 150 wells, 72 springs and underflows of running waters, and 6 caves, in Haiti. In 102 wells, which is $68 \%$ of the total number of wells sampled, ostracods were found. Only 8 springs, 3 underflows of running waters, and 2 caves, yielded ostracods. In one cave Strandesia cavernicola Broodbakker, 1983d, was discovered, and in another Darwinula cf. stevensoni, both species that were not found in any other sample from Haiti.

Except for a male specimen of a Pseudocandona species, all species which have been found in springs and underflows of running waters are also common in wells. In the wells some species were found only once: Candonopsis hummelincki, also found in many other Antillean islands, and Caribecandona auricularia and $C$. ansa, both species closely related to $C$. trapezoidea, which was found in a number of wells. The Caribecandona species, which are described and discussed in Broodbakker (1983c), are the only species encountered in Haiti, and even the West Indian islands, that are clearly stygobiont. Practically all other ostracod species found in Haiti, Cuba and the other islands are more or less epigean species, with the possible exception of a few species which will be discussed in the section on Cuba.

Other species which were encountered only once in the wells, are: Strandesia pistrix Broodbakker, 1983d, and a male specimen of an unknown species of Strandesia (Broodbakker, 1983d), Cypris subglobosa, C. decaryi, and an unknown species of Cypris. The first two Cypris species are likewise common in some of the West Indian islands, being species which commonly live in epigean waters, like pools and ponds.

The most common species in the wells of Haiti are the epigean species Strandesia longula, S. stocki, Chlamydotheca unispinosa, and Cypretta spp. The distribution and ecology of the first two species is extensively discussed in Broodbakker (1984a). Chlamydotheca unispinosa was found only once in Cuba, twice on Grand Cayman, and a few times in the Bahamas. It is a common species in the southern parts of the U.S.A., Central America, and South America, and is even found in Hawaii (Kotzian, 1974). It is probably much more common in the West Indian islands, but rarely encountered during this study since most Chlamydotheca species are burrowing species of muddy, epigean habitats. Cypretta spp. are very common in most West Indian islands, especially in wells.

Other species encountered in a number of wells are: Stenocypris major, Physocypria sp. and Cypridopsis sp.; Neocypridopsis inaudita was found twice in covered wells.

\section{CUBA}

(Table I: nr. 43)

Dr. L. Botosaneanu, Dr. T. Orghidan and other members of the Cubano-Romanian Expeditions in 1969, 1970 and 1973, sampled many caves in Cuba, but also a few pools and underflows of running waters. Danielopol (1972) described a new species, Danielopolina orghidani, from an anchyhaline cave sampled by these expeditions. This species is closely related to species of the genus Thaumatocypris which is only represented by species living in the deepsea. It is the only species known in the Carib- 
bean which must have originated by a "regression type" of evolution, from marine ancestors.

Furthermore, Danielopol (1982) described Candonopsis cubensis from another (freshwater) cave, in Cuba, a species which proved to belong to the new genus Caribecandona, described in Broodbakker (1983c), a genus endemic to Cuba and Hispaniola. It is also the only representative of the subgenus Cubacandona, which is supposed to be endemic to Cuba.

Through Dr. Danielopol I received 24 ostracod samples from caves in Cuba. Pseudocandona antilliana Broodbakker, 1983c, was found in part of these samples, but also in samples from a pool and from the underflow of running waters (Broodbakker, 1983c). Ps. cubensis Broodbakker, 1983c, probably an interstitial species, was found twice in the underflow of running waters, and could be endemic to Cuba. Two possibly stygobiont species of Strandesia, $S$. botosaneanui and $S$. cavernicola, were also encountered in the caves (Broodbakker, 1983d). The first species seems to be endemic to Cuba, while the second has been found in a cave in Haiti as well. $S$. cavernicola seems to have a reduced eye, as compared with other Strandesia species encountered in the Caribbean (Broodbakker, 1983d). If $S$. cavernicola really is a stygobiont species, this could indicate further proof of a former connection between Cuba and Haiti, as proposed by Hedges (1982).

$S$. longula and $S$. stocki were found in the few epigean samples, as well as a variety of Hemicypris. exigua different from populations in other islands by the reticulated inner side of its carapace (Broodbakker, 1983b).

Neocypridopsis inaudita and $N$. mexicana (Furtos, 1938) were found in four and six cave samples, respectively. Both species have been described (as Cypridopsis) from cenotes and caves in Yucatan. $N$. inaudita is also found in epigean samples from Yucatan and other West Indian islands, but $N$. mexicana only in caves in Cuba. This, combined with the fact that $N$. mexicana is one of the smallest freshwater ostracod species presently known, could mean that $N$. mexicana is a stygobiont species, and therefore could indicate proof of a former connection be- tween Yucatan and Cuba, since it is practically impossible for hypogean freshwater species to cross a sea barrier.

Darwinulids, which were not further identified, were found in many of the cave samples. Other species found in the few pools, holes in limestone, holes of landcrabs and the underflow of running waters, include: Cytheridella ilosvayi Von Daday, 1905, Physocypria sp., Cypretta sp., Cypridopsis sp., Cypris sp., Eucypris sp., and Ilyocypris sp.

Since most samples are from caves, and only a few from other habitats, it is not possible to get an overall view of the ostracod fauna of Cuba, or to compare the ostracod fauna found, with that of the other islands.

\section{JAMAICA, CAYMAN ISLANDS}

(Table I: nrs. 44 to 46 )

In Jamaica only seven wells have been sampled, of which three yielded ostracods (Cypridopsis sp.). Of the 36 samples from springs and the underflows of running waters, only 5 yielded ostracods. Pseudocandona caribbeana Broodbakker, 1983c, was found twice, and both Stenocypris major and Cypridopsis sp. were found once. In the few brackish karst lakes and karst holes sampled, representatives of the subfamily Thalassocypridinae were found. In the four stagnant waters and two rivulets sampled by Dr. Wagenaar Hummelinck, no ostracods were found.

Of the 24 wells sampled in both Grand Cayman and Cayman Brac, 14 yielded ostracods. Only Cypretta spp., Cypridopsis sp., Physocypria sp., and Strandesia longula were found. Of the 8 pools and the single natural hole in coral rock sampled in Grand Cayman, 5 yielded the same species, except for $S$. longula. Furthermore, Chlamydotheca unispinosa, Neocypridopsis inaudita and two undetermined species, probably belonging to the genus Candonocypris, were found.

The number of stations yielding ostracods, sampled in Jamaica and the Cayman Islands, is not sufficient to allow any conclusion about the ostracod fauna of these islands. 


\section{BAHAMAS \& CAICOS ISLANDS}

(Table I: nrs. 47 to 54 )

These islands are very poor in ostracod species, probably because they have been inundated by seawater some 65000 years ago (Pregill \& Olson, 1981). As recent as some 17000 years ago the Great Bahama Bank must have been a single emergent land mass because of a sea level drop of about $120 \mathrm{~m}$. Later on, the land mass was split up in five major island complexes, and at present only small land patches remain, which are still further receding (Pregill \& Olson, 1981).

Only wells, water holes in coral rock, one cave and a bore hole yielded ostracods in the islands listed in table I under the nrs. 47 to 54 . The most common species in the wells of these islands are Cypretta spp., Cypridopsis sp., Physocypria sp. and Strandesia longula. Neocypridopsis inaudita was found in wells on Mayaguana, Inagua, Crooked Island, Eleuthera, and in a cave on Inagua. Heterocypris punctata was encountered twice on South Caicos, Cypris decaryi once on Eleuthera, Darwinula sp. once on Mayaguana, and Chlamydotheca unispinosa twice on Providenciales, and twice on Crooked Island.

Most of the species mentioned are commonly found in pools and other epigean habitats in other islands of the West Indies, and are therefore probably much more common in the Bahamas than the data at hand would suggest. The only pool sampled in Eleuthera yielded Stenocypris major, Cypretta sp. and Neocypridopsis inaudita.

\section{THE OSTRACODS IN WELLS}

The relative abundance of the most common ostracod species in the Lesser Antilles (except for the Virgin Islands) in wells, becomes clear from table II, in which for each species the abundance in wells and in epigean lentic habitats like pools, ponds, basins, cisterns etc., is compared with the expected abundance in these two types of habitats if the species would have no preferences. As reference the total number of habitats concerned in the islands where each of the species is more or less common has been calculated. For most species the Lesser Antilles, except for the Virgin Islands, but including the Peninsula de Paraguana, were used as reference area.

In the Virgin Islands, Haiti, the Cayman Islands and the Bahamas, wells formed the greatest part of the stations sampled, which makes it impossible to compare the ostracod fauna of different habitats for these islands.

Cypris subglobosa was only found in 16 epigean habitats on Curaçao, Bonaire, Barbados, Marie Galante and Guadeloupe, and only once in a well. In Puerto Rico it was found in two epigean habitats, and in Haiti in a polluted open well. It is clear that this species is truly epigean, which could also be the reason why it was almost never found in the Virgin Islands, and the islands west of these, since in these islands practically no epigean stations have been sampled. The same holds true for all Hemicypris species (Broodbakker, 1983b) and Tanycypris meridana (see: Broodbakker, 1984b).

Cypris decaryi was found somewhat less frequently in the wells of Bonaire and Curaçao than in epigean habitats, but this difference was not statistically significant.

Heterocypris margaritae was found more often in wells, but not significantly, while $H$. antillensis was found significantly more often in epigean habitats (see also: Broodbakker, 1983a).

Neocypridopsis inaudita seems to be found more often in wells (and caves), but this difference could not be tested since only few samples yielding this species are available. However, it was also encountered in two covered wells in Haiti, in sixteen wells and water holes in coral rock and in one cave, in the Bahamas, and in caves in Cuba. It seems therefore to have its main distribution in hypogean habitats.

Stenocypris major and Potamocypris hummelincki were found significantly more often in epigean habitats, nothwithstanding the fact that Stenocypris major was found in 18 wells in Haiti (table III).

Physocypria affinis, Cypridopsis sp., and Chlamydotheca barbadensis seem to have no preference for either wells or epigean habitats. 
TABLE II

Number of ostracod samples from lentic habitats and from wells, compared with the total number of ostracod samples in the respective habitats and islands, with percentages and $G$-values (ref. = reference).

\begin{tabular}{|c|c|c|c|}
\hline & $\begin{array}{l}\text { Number of pools, } \\
\text { ponds, ditches, etc. }\end{array}$ & $\begin{array}{l}\text { Number of wells, } \\
\text { sink- and bore holes }\end{array}$ & $G$-value \\
\hline $\begin{array}{l}\text { Cypris decaryi } \\
\text { Ref.: Curaçao, Bonaire }\end{array}$ & $\begin{array}{l}21(78 \%) \\
88(68 \%)\end{array}$ & $\begin{array}{r}6(22 \%) \\
42(32 \%)\end{array}$ & 1.34 \\
\hline $\begin{array}{l}\text { Heterocypris margaritae } \\
\text { Ref.: Islands } 3 \text { to } 12 \text {, and Paraguana }\end{array}$ & $\begin{array}{r}23(55 \%) \\
126(65 \%)\end{array}$ & $\begin{array}{l}19(45 \%) \\
68(35 \%)\end{array}$ & 1.85 \\
\hline $\begin{array}{l}\text { Heterocypris antillensis } \\
\text { Ref.: Islands } 3 \text { to } 6,25,31\end{array}$ & $\begin{array}{r}36(80 \%) \\
127(65 \%)\end{array}$ & $\begin{array}{r}9(20 \%) \\
67(35 \%)\end{array}$ & $4.61^{*}$ \\
\hline $\begin{array}{l}\text { Neocypridopsis inaudita } \\
\text { Ref.: Islands 5, 6, 28, } 30 \text { to } 32\end{array}$ & $\begin{array}{r}2(20 \%) \\
69(54 \%)\end{array}$ & $\begin{array}{r}8(80 \%) \\
59(46 \%)\end{array}$ & - \\
\hline Stenocypris major & $60(87 \%)$ & $9(13 \%)$ & $23.30^{* *}$ \\
\hline Potamocypris hummelincki & $55(82 \%)$ & $12(18 \%)$ & $14.36^{* *}$ \\
\hline Cypretta sp. & $16(25 \%)$ & $48(75 \%)$ & $33.64^{* *}$ \\
\hline Physocypria affinis & $31(65 \%)$ & $17(35 \%)$ & 0.31 \\
\hline Cypridopsis sp. & $25(66 \%)$ & $13(34 \%)$ & 0.42 \\
\hline Chlamydotheca barbadensis & $15(58 \%)$ & $11(42 \%)$ & 0.10 \\
\hline Ref.: Islands 3 to 33 and Paraguana & $176(61 \%)$ & $114(39 \%)$ & \\
\hline
\end{tabular}

\section{TABLE III}

Number of ostracod samples, with percentages and $G$-values, from wells in Haiti and the Bahamas (fur further explanation see text).

\begin{tabular}{llllll}
\hline HAITI & $\begin{array}{l}\text { In all wells } \\
\text { Accompanying Ostracoda }\end{array}$ & $\begin{array}{l}\text { Cypretta sp. } \\
(n(2)=98)\end{array}$ & $\left(n_{(1)}=39\right)$ & $G$ & \multicolumn{2}{c}{$\begin{array}{c}\text { Chlamydotheca unispinosa } \\
(n=37)\end{array}$} & $G$ \\
\hline Clamydotheca unispinosa & $37(38 \%)\left(n_{t}\right)$ & $16(15 \%)$ & $9.49^{* *}$ & & \\
Strandesia stocki & $39(40 \%)$ & $13(33 \%)$ & 0.69 & $12(32 \%)$ & 0.86 \\
Strandesia longula & $33(34 \%)$ & $22(56 \%)$ & $8.42^{* *}$ & $6(16 \%)$ & $5.72^{*}$ \\
Stenocypris major & $18(18 \%)$ & $8(21 \%)$ & 0.12 & $3(8 \%)$ & $3.89^{*}$ \\
Physocypria sp. & $12(12 \%)$ & $6(15 \%)$ & 0.33 & $5(14 \%)$ & - \\
Cypridopsis sp. & $7(7 \%)$ & $3(8 \%)$ & - & $3(8 \%)$ & - \\
\hline BAHAMAS & In all wells & Physocypria sp. & \multicolumn{2}{c}{ Cypridopsis sp. } \\
Accompanying Ostracoda & $(n=81)$ & $(n=45)$ & $G$ & $(n=38)$ & $G$ \\
\hline Cypridopsis sp. & $38(47 \%)$ & $19(42 \%)$ & 0.40 & & \\
Strandesia longula & $38(47 \%)$ & $16(36 \%)$ & 2.37 & $21(55 \%)$ & 1.06 \\
Cypretta sp. & $22(27 \%)$ & $10(22 \%)$ & 0.58 & $10(26 \%)$ & 0.01 \\
Neocypridopsis inaudita & $16(20 \%)$ & $7(16 \%)$ & 0.53 & $7(18 \%)$ & 0.04 \\
\hline
\end{tabular}

* Significant at better than $5 \%$ level (one-tailed).

** Significant at better than $1 \%$ level (one-tailed).

The first two genera are also common in wells of the Virgin Islands, Haiti, and the Bahamas.

Cypretta sp. was found significantly more often in wells. Some or perhaps all species of this genus seem to be most abundant in the wells of practically all West Indian islands.

In the wells of the Virgin Islands Cypretta sp. is the most common species, being present in 29 
out of 39 wells and water holes in coral rock sampled, followed by Physocypria sp. (in 12 wells) and Cypridopsis sp. (in 7 wells). Most other species encountered were found only once, except for Strandesia longula which was found in four wells, and Neocypridopsis inaudita and Neocypridopsis sp., wich were found in three shallow water holes in coral rock in Anegada.

In the wells of Haiti and the Bahamas the species listed in table III were most abundant, including the two Strandesia species already discussed by Broodbakker (1984a).

Chlamydotheca unispinosa is one of the most common species in the wells of Haiti, while it is practically absent in the wells of the Bahamas. This species was scarce in the epigean samples from the other islands, while it is also known from some states in the U.S.A., from Yucatan, from Brazil and Argentina and from Hawaii (Kotzian, 1974). The reason for its scattered distribution and its absence in wells in other islands, especially in the Lesser Antilles, remains unsolved. It could be that there is some form of competition between Chl. unispinosa and Chl. barbadensis, this last species being especially common in some of the Lesser Antilles.

Cypridopsis sp. is especially common in wells of the Bahamas, and much less in wells of Haiti. Most of these Cypridopsis sp. have the shape of C. vidua, but they are smaller and do not possess the characteristic dark markings on the carapace, which could be due to fixation in formalin. It is quite possible that most of the Cypridopsis species encountered in the West Indies have to be assigned to $C$. vidua. Something similar holds true for Cypretta species, the most common species in wells of the West Indies. It could be that most of them belong to $C$. sarsi, a species which was poorly described by Brady (1902) from St. Thomas (Virgin Islands).

Physocypria sp., of which I did not study the taxonomy, is most common in wells of the Bahamas, but it was also found in most other West Indian islands.

Only for the Bahamas as a whole, and for Haiti, it was possible to calculate if some species are found more often or less often than expected in each other's presence in wells than expected from their overall distribution in the wells of the islands considered. This was already calculated for Strandesia longula and $S$. stocki by Broodbak$\operatorname{ker}$ (1984a), $S$. longula being found significantly more often in the presence of Cypretta sp., and significantly less often in the presence of Chlamydotheca unispinosa, than expected. Likewise, Cypretta sp. was found much less frequently in the presence of Chl. unispinosa than expected (table III). The other species in the wells of Haiti and the Bahamas were not found significantly more or significantly less often in each other's presence, than expected.

An attempt was made to compare the abundance of the most common species in different environmental classes in wells, with that expected, as was done for species of the genus Heterocypris by Broodbakker (1983a). The factors chosen were: light conditions, position of the water table, and water depth. For the species in the wells of the Lesser Antilles not enough data were available, since most species were encountered in less than 15 wells only (cf. table II), and because the factors tested were not always measured or indicated. Testing was possible only for Cypretta sp. in the Virgin Islands, and for the most abundant species found in Haiti and the Bahamas (cf. table III). No significant differences were found in distribution of these species as far as light conditions, position of the water table and water depth are concerned. The data and $G$-values calculated are therefore not listed in this article.

\section{ACCOMPANYING FAUNA IN WELLS}

Especially the joint occurrence of hadziid amphipods and ostracods is studied. The genus Metaniphargus belongs to the larger hypogean amphipods of the hadziid group. Stock (1983) made it likely that hadziid amphipods can be effective predators of small crustaceans, like cyclopid copepods and the small-sized crustaceans of the hypogean order Thermosbaenacea.

On Curaçao Metaniphargus was found in 45 of the 54 wells sampled. Cypridopsis sp. was found in 9 and Cypretta sp. in 4 of the 11 genuine wells 
yielding ostracods, Cypridopsis in 5, and Cypretta in 2 wells together with Metaniphargus. This could mean that Cypretta and especially Cypridopsis are better fitted against predation by Metaniphargus than other ostracod species. Unfortunately, 7 ostracod samples from stations yielding Metaniphargus have got lost. Furthermore, Cypridopsis is common not only in wells, but also in pools, ponds and similar habitats on Curaçao, while it is absent on Bonaire and most Venezuelan islands. It was found only once on Aruba and Margarita. If Cypridopsis sp. is more resistant against predation by Metaniphargus, the question of its abundance in epigean habitats and of its absence in the neighbouring islands remains unsolved.

On Aruba only 7 out of 41 genuine wells sampled yielded ostracods. Fourteen wells yielded Metaniphargus but no ostracods. In one well Metaniphargus was found together with Cypretta. It is strange that on Aruba Heterocypris margaritae, a species well adapted to brackish wells (Broodbakker, 1983a), is only found in pools, brooklets and springs, and only present in one pool on Curaçao. It could be that its absence in the wells of these islands is caused by the abundance of Metaniphargus there.

On Guadeloupe 5 wells and 4 pump stations have been sampled. Metaniphargus was found in 4 pump samples and in 2 of the wells. In only one other well a juvenile of Stenocypris major was found. Since only few wells have been sampled on Guadeloupe it is not evident if the absence of ostracods is caused by the presence of Metaniphargus.

On Antigua 15 wells have been sampled of which only 1 yielded Metaniphargus and 6 others yielded ostracods.

On Barbuda 2 caves and 13 wells have been sampled. The two caves and six of the wells yielded Metaniphargus. Only two other wells yielded ostracods. The fact that Metaniphargus is common on this island and that only two wells yielded ostracods, could indicate some mutual influence. However, on St. Eustatius only 4 out of the 17 wells sampled yielded ostracods, while Metaniphargus is not found on this island.

On Anguilla 9 out of 11 natural crevices and wells sampled yielded ostracods. In all but one of these samples Neocypridopsis inaudita was found together with Metaniphargus. In the other sample Perissocytheridea cribrosa and Metaniphargus were found.

Hadziid amphipods were also encountered in St. Croix, Jamaica and Haiti, but not in the Virgin Islands and the Bahamas. On St. Croix only one out of twelve wells sampled yielded ostracods, belonging to the genus Physocypria. Hadziid amphipods were only found in one other well.

Only from Haiti enough data are present to compare statistically the presence of the most common ostracods with the presence of hadziid amphipods, as is done in table IV. Neither of the species listed was found significantly less in the presence of hadziid amphipods. Only Strandesia longula was found significantly less in the presence of hadziid amphipods, while $S$. stocki did not seem to be influenced, as was calculated in Broodbakker (1984a: table II).

Cypretta spp. are the only species which have been found in large enough numbers to compare their presence with that of Metaniphargus for all sampled Lesser Antilles together. These species were not found significantly less in the presence of Metaniphargus than expected (table IV).

The presence of ostracods in the wells was also compared with that of other faunal groups. In the Lesser Antilles, only Cypretta was found in the wells often enough to compare its abundance with that of other faunal groups, but the differences found were not statistically significant.

For Haiti and the Bahamas joint occurrence could be statistically tested for the most common species, as is shown in table IV. However, no significant differences with the expected joint occurrence could be found, except for Neocypridopsis inaudita in the Bahamas, which was found significantly more often than expected in the presence of Oligochaeta.

\section{EPIGEAN VERSUS HYPOGEAN OSTRACODA}

Most of the wells in the West Indies are colonized by epigean animals, especially Cyclopidae, 
TABLE IV

Number of samples (ostracods versus other faunal elements), with percentages and $G$-values, from wells in most Lesser Antilles, the Virgin Islands, Haiti and the Bahamas (for further explanation see text).

\begin{tabular}{|c|c|c|c|c|c|c|c|}
\hline $\begin{array}{l}\text { ISLANDS } 3 \text { TO } 33 \\
\text { AND } \\
\text { PARAGUANA } \\
\text { Accompanying fauna }\end{array}$ & $\begin{array}{l}\text { In all wells } \\
\text { yielding } \\
\text { Ostracoda } \\
(n=129)\end{array}$ & $\begin{array}{l}\text { In wells } \\
\text { yielding } \\
\text { Cypretta sp. } \\
(n=43)\end{array}$ & $G$ & VIRGIN ISLANDS & $\begin{array}{l}\text { In all wells } \\
\text { yielding } \\
\text { Ostracoda } \\
(n=39)\end{array}$ & $\begin{array}{l}\text { In wells } \\
\text { yielding } \\
\text { Cypretta sp. } \\
(n=29)\end{array}$ & $G$ \\
\hline Hadziid amphipods & $17(13 \%)$ & $4(9 \%)$ & 0.62 & Thermosbaenacea & $12(31 \%)$ & $10(34 \%)$ & 0.18 \\
\hline Cyclopidae & $55(43 \%)$ & $24(56 \%)$ & 3.01 & Cyclopidae & $24(62 \%)$ & $16(55 \%)$ & 0.49 \\
\hline Mosquito larvae & $20(16 \%)$ & $9(21 \%)$ & 0.39 & Mosquito larvae & $6(15 \%)$ & $5(17 \%)$ & - \\
\hline Oligochaeta & $17(13 \%)$ & $7(16 \%)$ & 0.34 & Oligochaeta & $10(26 \%)$ & $9(31 \%)$ & 0.42 \\
\hline
\end{tabular}

\begin{tabular}{|c|c|c|c|c|c|c|c|c|}
\hline Accompanying fauna & $\begin{array}{l}\text { In all wells } \\
\text { yielding } \\
\text { Ostracoda } \\
(n=98)\end{array}$ & $\begin{array}{l}\text { In wells yi } \\
\text { Cypretta sp. } \\
(n=39)\end{array}$ & elding & $\begin{array}{l}\text { Chlamydoth } \\
\text { unispinosa } \\
(n=37)\end{array}$ & $G$ & $\begin{array}{l}\text { Stenocypris } \\
\text { major } \\
(n=18)\end{array}$ & $G$ & $\begin{array}{l}\text { Physocypria sp. } \\
(n=12)\end{array}$ \\
\hline Cyclopidae & $81(84 \%)$ & $29(74 \%)$ & 1.68 & $34(92 \%)$ & 2.64 & $13(72 \%)$ & 一 & $10(83 \%)$ \\
\hline Oligochaeta & $55(57 \%)$ & $22(56 \%)$ & 0.01 & $22(59 \%)$ & 0.17 & $7(39 \%)$ & 2.15 & $7(58 \%)$ \\
\hline Cladocera/Phyllopoda & $20(21 \%)$ & $5(13 \%)$ & 1.54 & $10(27 \%)$ & 0.93 & -- & 一 & $5(42 \%)$ \\
\hline Thermosbaenacea & $26(27 \%)$ & $11(28 \%)$ & 0.06 & $11(30 \%)$ & 0.20 & $7(39 \%)$ & 1.30 & $2(17 \%)$ \\
\hline Hadziid amphipods & $18(19 \%)$ & $4(10 \%)$ & 1.97 & $10(27 \%)$ & 1.67 & $3(17 \%)$ & 一 & $2(17 \%)$ \\
\hline
\end{tabular}

\begin{tabular}{|c|c|c|c|c|c|c|c|c|c|}
\hline \multirow{2}{*}{$\begin{array}{l}\text { BAHAMAS } \\
\text { Accompanying fauna }\end{array}$} & \multirow{2}{*}{$\begin{array}{l}\text { In all wells } \\
\text { yielding } \\
\text { Ostracoda } \\
(n=81)\end{array}$} & \multicolumn{2}{|c|}{$\begin{array}{l}\text { In wells yielding } \\
\text { Physocypria sp. }\end{array}$} & \multicolumn{2}{|c|}{ Cypridopsis sp. } & \multicolumn{2}{|l|}{ Cypretta sp. } & \multicolumn{2}{|c|}{$\begin{array}{l}\text { Neocypridopsis } \\
\text { inaudita }\end{array}$} \\
\hline & & $(n=45)$ & $G$ & $(n=38)$ & $G$ & $(n=22)$ & $G$ & $(n=16)$ & $G$ \\
\hline Cyclopidae & $43(53 \%)$ & $24(53 \%)$ & 0.01 & $25(66 \%)$ & 2.52 & $13(59 \%)$ & 0.32 & $7(44 \%)$ & 0.56 \\
\hline Oligochaeta & $24(30 \%)$ & $11(24 \%)$ & 0.60 & $13(34 \%)$ & 0.37 & $5(23 \%)$ & 0.53 & $10(63 \%)$ & $7.15^{* *}$ \\
\hline Cladocera/Phyllodopa & $10(12 \%)$ & $5(11 \%)$ & 0.07 & $5(13 \%)$ & - & $5(23 \%)$ & - & $2(13 \%)$ & - \\
\hline Hyalella sp. & & & & & & & & & \\
\hline (Amphipoda) & $12(15 \%)$ & $8(18 \%)$ & 0.30 & $6(16 \%)$ & - & $3(14 \%)$ & 一 & $1(6 \%)$ & - \\
\hline
\end{tabular}

** Significant at better than $1 \%$ level (one-tailed).

insect larvae and Gastropoda. Since most of the ostracod species colonizing wells are often encountered in large numbers, it is clear that they can ecologically adapt to life in wells. However, not all species seem to be capable of colonizing wells, or they are competitively excluded by other ostracod species. Compared with all other ostracod species, Cypretta spp., Cypridopsis spp., and Physocypria spp., are most often encountered in wells. Many epigean species were never or almost never found in genuine wells, e.g. all Hemicypris species (Broodbakker, 1983b), Tanycypris meridana (see Broodbakker, 1984b), and Cypris subglobosa (only in one well in Haiti). For species of the genera Heterocypris and Strandesia, this aspect is discussed in Broodbakker (1983a, 1984a).

Ostracod diversity in wells is low. In most of the samples only one or two species are present. When the well is more open and shallow, it begins to resemble epigean habitats and two or three species can be encountered. In true epigean habitats, like pools, up to six species can be present in a single sample. Furthermore, 
in different seasons other species combinations can be found. The species found in pools include those found in wells. This is in agreement with the findings of Danielopol (1981), who records likewise low diversities in wells of Euboea (Greece). Danielopol grouped his wells in six types (I to VI) from more epigean and polluted to covered, unpolluted wells sheltering hypogean animals. The epigean animals live in Euboea in the uncovered wells with polluted waters. In his case a low number (two) of real hypogean ostracod species was found, while in the West Indian islands, except for Cuba and Hispaniola, no hypogean animals were encountered at all. All wells, if colonized, were invaded by epigean, euryoecious species. Species belonging to genera like Heterocypris, Hemicypris and Strandesia can display much variability in length, probably related to ecological factors, but seem to be genetically stable (Broodbakker, 1983a-b, 1984a). It appears that some species can ecologically adapt to life in wells, but the populations living in wells do not differ morphologically from populations living in epigean habitats.

Apparently, the freshwater ostracods living in the Lesser Caribbean Islands and in the Bahamas, were unable to evolve into hypogean species. This is probably due to their ecologic plasticity, combined with their large potentials for passive dispersal, especially of their eggs, from island to island, and from pool to pool or well. Probably there is a large amount of gene flow in the sexual species, and a strong genetic stability in the parthenogenetic ones.

Other groups which could colonize the groundwater are the marine interstitial, marine, and brackish-water species, especially in the Antillean islands which are slowly but constantly rising since many thousands of years, or even millions of years. In this way marine animals may have "stranded", and gradually adapted to nonmarine conditions, especially by way of the partly. or wholly brackish groundwater of the semi-arid islands, which are poor in surface water. This zoogeographic model, the Regression Model, is advocated by Stock in many papers, for a great deal on hypogean Crustacea (e.g. Stock, 1977, 1980).

However, no hypogean Ostracoda with direct or less direct marine ancestors were found in any inland groundwater sample from any island. Only one epigean brackish-water ostracod, Perissocytheridea cribrosa, has colonized some of the more brackish wells, but it did not evolve into a hypogean species either.

It seems that there are no ostracod species for which it was possible to overcome the barrier from salt to fresh water. Most of the interstitial ostracods living in the vicinity of the sea in the Neotropics are still living in $18 \%$ chlorinity or close to that (see e.g. Hartmann, 1974).

As Danielopol (1981) described for Euboea, wells behave like islands, and are colonized by both hypogean and epigean species. However, in the case of the ostracods of all smaller West Indian islands, the balance seems to have turned in favour of the more or less cosmopolitan epigean species.

\section{ZOOGEOGRAPHY}

There is much controversy concerning the origin of the West Indian islands and of their fauna. Most of the opinions are concerned with the "Dispersal" and the "Vicariance Model" of origin.

The Dispersal Model has gained acceptance chiefly through the works of Darlington (e.g. 1957). It assumed that the Antillean islands have originated independently and have been populated by transmarine migrants, by way of active or passive dispersal.

The most cited propagators of the Vicariance Model are Rosen (1976), for the Caribbean, and Croizat (e.g. 1976) for the general theory. Rosen assumes the Antillean islands to be fragments of a proto-Antillean contiguous area forming the connection between North and South America in the Late Mesozoic. This proto-Antillean plate has moved in northeastern direction and has split up eventually in the presently existing islands and plates, in the Late Tertiary. 
Hedges (1982) has recently compiled new geologic evidence of a vicariant origin of the Greater Antilles, including the Virgin Islands which are situated on the Puerto Rican bank. He remains in doubt about the origin of the other Lesser Antilles.

With respect to the Vicariance Model of origin of the Caribbean islands, many data are derived from flatworms (e.g. Ball, 1971), Orthocladiinae (Chironomidae) (Sæther, 1981), Trichoptera (Ross, 1967; Botosaneanu, 1979, only for the Greater Antilles), freshwater fauna in general (Harrison \& Rankin, 1976), and freshwater fishes (Rosen, 1976). Likewise, Rosen (1976) derived data from epigean freshwater shrimps of the family Atyidae and the hypogean genus Thyphlatya, which were refuted by Stock (1981).

In favour of the Dispersal Model of origin of the Caribbean fauna many indications are derived from the distribution of reptiles (e.g. Müller, 1973), bats (Baker \& Genoways, 1978), insects like butterflies (Brown, 1978), and freshwater Gastropoda (Baker, 1945).

Recent discussions concerning both models of origin of fauna, can be found in Nelson \& Rosen (1981) and Nelson \& Platnick (1981).

Freshwater organisms which accomplish their entire life cycle in fresh water often have limited dispersal abilities, and could therefore be excellent objects for testing the different models. Freshwater ostracods partly, agree with these requirements; however, most of them have extensive abilities for passive dispersal. Passive dispersal of ostracods can take place by way of their eggs, or of adult animals.

The eggs of many freshwater species, especially the Cypridinae, are very resistant against all types of physico-mechanical stress. They are first of all desiccation resistant by way of a protective double wall (Van Morkhoven, 1962). Sars (e.g. 1889, 1901) raised many species of Cypridinae in cultures from dried mud sampled in various continents of the world. A case is known in which a Cypris species was raised from dried mud sent from the Near East to Great Britain, some 24 to $30^{\prime}$ years previously (Van Morkhoven, 1962).
Sohn \& Kornicker (1979) froze and freezedried eggs of Heterocypris incongruens (Ramdohr, 1808) at -25 to $-30^{\circ} \mathrm{C}$ and at $0.01 \mathrm{mb}$ vacuum. These eggs still hatched after immersion in water. In this way it is possible for ostracods with such resistant eggs to be widely distributed because of circumglobal transport of eggs by high altitude winds at low temperature and pressure.

Some species, especially some Candoninae, can enter in a torpid state when the situation becomes unfavourable (Delorme \& Donald, 1969; McLay, 1978). Especially for species with less resistant eggs or with brood care, this seems a good way to survive less favourable conditions, or to be dispersed.

There are several possible ways of passive dispersal for ostracods and their eggs. Most of these are listed in McKenzie (1971):

(1) Ovigerous females or nonovigerous parthenogenetic species, or their eggs, can be carried across oceans and other barriers in mud caked to the feathers and feet of migrant or stormdriven birds, especially waterfowl (Sandberg, 1964; De Deckker, 1977). There is a migration route of wading birds and ducks from Venezuela over Trinidad, Grenada, up north, and further over St. Kitts, St. Thomas, Puerto Rico, Haiti, Jamaica, to Cuba. This dispersal route is postulated to be the essential way for gastropod species of the family Planorbidae to reach the Antillean islands (Baker, 1945).

Over shorter distances even insect carriers could be effective for dispersal of ostracods (Fryer, 1953).

(2) Dusty, moisty and even dry wind or gales could be a way of dispersal of desiccation resistant eggs, and perhaps even of adults in a torpid state (McKenzie, 1971).

(3) Eggs or even complete specimens could be dispersed via the alimentary canal of birds (Proctor, 1964; Proctor \& Malone, 1965), or the guts of fishes in case of marine ostracods (Kornicker \&ohn, 1971).

(4) Introduction by man, by way of water barrels or ballast tanks on ships, or mud on boots or ships. Unfortunately, this is hard to prove in most cases. It is a proven way of dispersal in the 
case of rice-introduction in European countries (e.g. Petkovski, 1964).

It will be clear that most freshwater ostracods, except for the hypogean species, have a limited value for fine scale zoogeography. Most of the freshwater ostracods encountered in the West Indies disperse relatively easily and are therefore widely distributed. Many species are parthenogenetic, which even more facilitates introduction after passive dispersal. McKenzie (1971) states that species of the genera Heterocypris, Cypridopsis, Chlamydotheca, and Cypretta, are the most common in islands. This statement is confirmed by the results of the present study. The genera Strandesia, Hemicypris and Physocypria have to be added to this list. This could indicate that these genera in particular have the best dispersal abilities. However, the genera Heterocypris and Cypridopsis are common throughout the world, while the genera Chlamydotheca, Cypretta, Strandesia and Hemicypris are common circumtropical genera. Most of the species encountered seem to be genetically stable and did not evolve into endemic species on the smaller islands.

This means that the greatest part of the freshwater ostracods of the West Indies must have arrived on the islands by passive dispersal, except perhaps for some species in Haiti and Cuba, which may have originated in these islands or in the former Proto-Antilles.

Therefore it should be possible to test some of the theories regarding the expected number of species in islands. MacArthur \& Wilson (1967) calculated relations between the number of species present and island area, and distance to the mainland, or to the centre of dispersal. Many authors used this model or extended the model with other variables, applying it to many animal groups, likewise in the West Indies.

However, only some islands were sampled extensively, other islands barely, and in many islands only wells and underflows of running waters have been sampled. Furthermore, only few species have been found in most of the islands, and it is highly probable that in most islands more species are present than those ac- tually encountered, as became evident in the chapter on distribution of the species. When the number of species is plotted against the number of stations yielding ostracods in each island, it is evident that the more samples have been taken, the more species are found (fig. 4).

There can be two reasons for this effect: One is the fact that when an island is larger, more stations to be sampled are available, whilst in a small island only few freshwater habitats are available and only few species are present. The other reason can be that the number of species encountered is truly correlated with the number of stations sampled. Curaçao and St. Martin yielded the same number of species, Aruba one less and Bonaire one more. St. Martin occupies approximately one-fifth of the size of Curaçao and one-third of the size of Bonaire. Aruba is about twice the size of St. Martin. According to their size and the theory, Curaçao should yield most species, Bonaire and Aruba less, and St. Martin the least. Haiti and Cuba yielded 20 and 19 species, respectively, whereas in Haiti three times as many samples yielded ostracods. Barbados and Margarita yielded the same number of species, and the number of samples was the same, but Barbados is far away from the continent and Margarita is situated on the continental shelf of Venezuela. Barbados is also much smaller than Margarita (fig. 1). In the islands where less than 14 samples yielded ostracods, a variation from 1 to 10 species was found.

Furthermore, other factors probably contribute to the number of species in an island. Volcanic islands have a structure different from that of calcareous islands, like greater altitudes, thus more precipitation and more freshwater habitats, although often of a torrential type, and can therefore yield more species than semiarid islands. This could explain the large number of species found on the small island St. Martin, as compared with the number of species on the largely calcareous islands, Aruba, Bonaire, and Curaçao.

The conditions in the more extensively sampled islands are too different to make a statistical comparison possible. Furthermore, in 


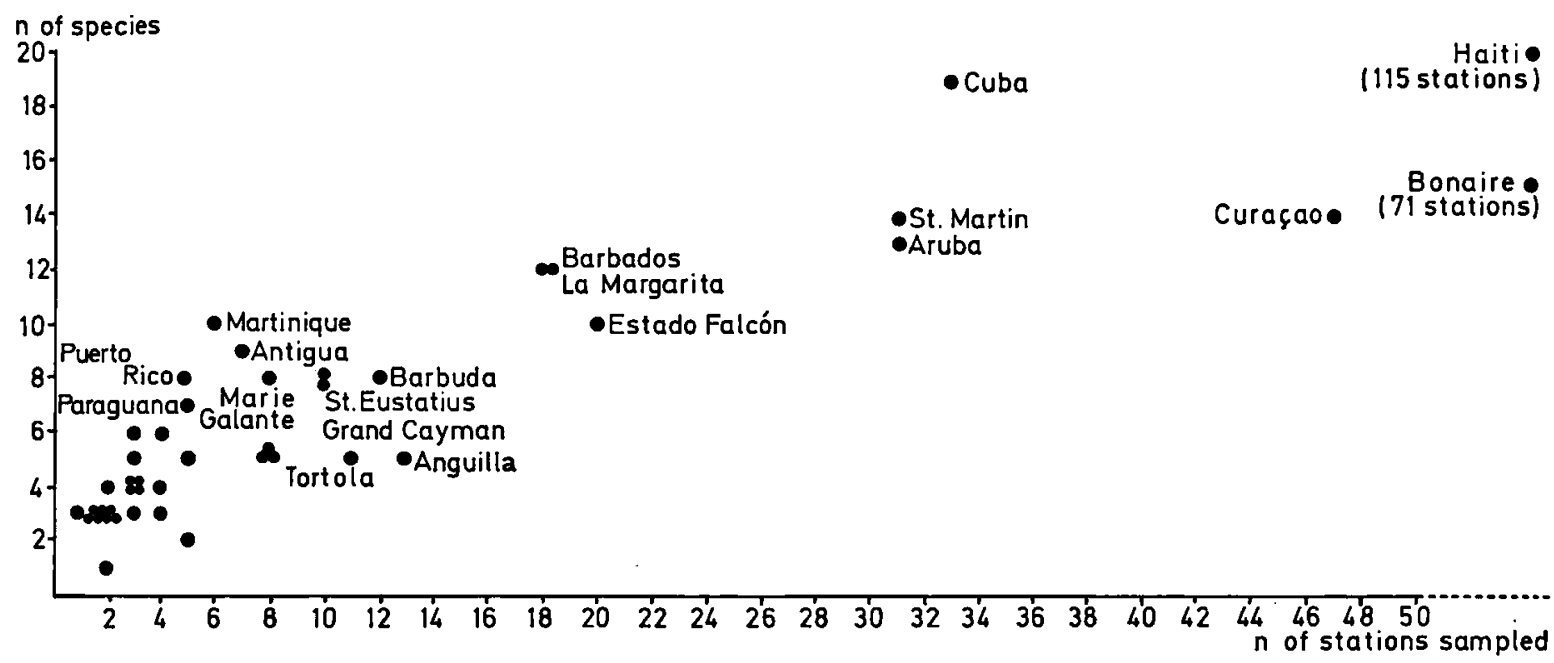

Fig. 4. Number of ostracod species encountered, versus number of stations sampled, in the various islands and regions. Only islands and regions in which more than six species were found are indicated by name.

Cuba mostly caves have been sampled, in Haiti mostly wells, and in the Netherlands Antilles all kinds of habitats. The few differences found do not indicate a species/area regression or a relationship to the distance from the mainland.

\section{ZOOGEOGRAPHICAL CONCLUSIONS}

It appears that the different Lesser Antilles have essentially the same ostracod fauna, with minor differences in some cases, like the abundance of Cypridopsis sp. on Curaçao, the occurrence of Hemicypris barbadensis on Barbados, the presence of Neocypridopsis sp. on Virgin Gorda and Anegada only, and the scattered distribution of many other species. However, most of these differences can probably be explained by insufficient sampling of most islands as far as ostracods are concerned. The only islands having a clearly different and partly specific fauna are Hispaniola and Cuba, which is probably also due to the fact that these islands have a large ecological diversity and extended physiography. Furthermore, there seems to be a barrier for some species between Puerto Rico and Hispaniola, but this could also be a result of selective sampling, especially because west of this boundary practically only wells, caves, and underflows of running waters have been sampled.

No consistent differences could be found either between the volcanic and the calcareous islands. This is partly due to the fact that the volcanic islands were sampled far less extensively.

All species in the Lesser Antilles, the Bahamas, and many of the species from Haiti and Cuba must have arrived there by passive dispersal. Some of them probably arrived from South America, others from the southern part of North America, and maybe some from a proto-Antillean centre of origin.

In Cuba one species, and in Haiti three species of ostracods have been found in the groundwater, belonging to the new genus Caribecandona Broodbakker, 1983c. This genus, which seems to be very old, could have originated in the Proto-Antilles. The genus is divided into two subgenera, one endemic to Cuba, the other to Haiti. This could be due to vicariance, viz. the separation of Cuba and Haiti, which could have taken place between 5 to 20 million years ago (Hedges, 1982). A relatively recent separation of Cuba and Haiti could also explain the presence of Strandesia cavernicola, a species which is postulated to be hypogean, in caves in Cuba, and in one cave in Haiti. 
Another striking fact is the presence of Neocypridopsis mexicana in many caves in Cuba. This species has been described by Furtos (1938) from a cave in Yucatan, Mexico. It is found only in hypogean habitats from Cuba, and therefore probably has limited dispersal abilities. This would mean that there must have been a connection between Yucatan and Cuba. According to the review of Hedges (1982), the most probable model of origin for at least the Greater Antilles, is the one of Dickinson \& Coney (1980), in which the Proto-Greater Antilles, a magmatic arc that emerged between South and North America, has moved northeastward, and split to give the Greater Antilles. For a long period this arc must have been in contact with Yucatan. However, the time of separation from Yucatan is postulated from 40 to 120 million years B.P. The genus Cypridopsis is believed to be 37 million years old, according to data of the fossil record (Van Morkhoven, 1962). This would mean that Neocypridopsis mexicana must be a very old species in order to explain its presence in Cuba as well as in Yucatan, by a vicariance event.

Unfortunately, no other clearly hypogean species belonging to the Candoninae were found in the caves and cenotes of Yucatan. Most of the species encountered by Furtos (1936) in Yucatan seem to be epigean. Some of them have also been found in the Caribbean islands. Among her species only Neocypridopsis mexicana and $N$. yucatanensis, both belonging to the smallest freshwater ostracods of the world $(0.35$ to $0.40 \mathrm{~mm})$, are possibly hypogean.

Only few stations in Puerto Rico, which could have been another part of the ProtoAntilles, yielded ostracods. The Virgin Islands, which are situated on the same bank as Puerto Rico, did not yield any hypogean ostracods, in spite of the fact that many stations yielding ostracods have been sampled on these islands.

The fact that none of the Lesser Antilles, of which some were extensively sampled, yielded hypogean ostracods, strengthens the hypothesis that most of these islands were no part of a proto-Antillean arc, but have emerged separately, or in groups, independent of the
Greater Antilles. This is in contrast with the opinion of Rosen (1975) and conform the opinion of Stock (1981).

In Jamaica, which is postulated by many authors to be a former part of a geotectonical plate independent of that of the Proto-Antilles (see review in Hedges, 1982 and Stock, 1983b), only few stations yielded ostracods. It remains therefore uncertain whether this island possesses any hypogean ostracod fauna, and if so, whether it is different from that in the Greater Antilles.

\section{ACKNOWLEDGEMENTS}

Dr. D. L. Danielopol is thanked for his support, his stimulating enthusiasm, his contributions in the form of copies of interesting papers and discussions, and especially the hospitality I could always enjoy in the Institut für Limnologie, Abteilung Mondsee, of the Österreichische Akademie der Wissenschaften.

Prof. Dr. J. H. Stock, coordinator of the Amsterdam Expeditions and of this project, is thanked for reading the many, sometimes hardly readible, drafts of all my articles on the ostracods of the West Indies, and for the opportunity he provided for me to write this thesis.

Dr. L. Botosaneanu and Drs. F. F. J. M. Pieters are thanked for scrutinizing my articles.

Dr. P. Wagenaar Hummelinck, Dr. L. Botosaneanu and Dr. T. Orghidan are thanked for placing their samples at my disposal.

This study has been financed by the Netherlands Foundation for the Advancement of Tropical Research (WOTRO), The Hague. The fieldwork of the Amsterdam Expeditions has been supported by grants from WOTRO, the Beijerinck-Popping Fonds (Amsterdam), the Treub Maatschappij (Utrecht), the Amsterdamse Universiteits Vereniging (Amsterdam), and the Fonds Landbouwhogeschool (Wageningen).

\section{REFERENCES}

Baker, F. C., 1945. The molluscan family Planorbidae: 1-530 (Univ. Illinois Press, Urbana).

BAKER, R. J. \&. H. Genoways, 1978. Zoogeography of Antillean bats. In: F. B. GiLl ed., Zoogeography in the Caribbean. The 1975 Leidy Medal Symposium. Spec. Publs. Acad. nat. Sci. Philad., 13: 53-97.

BaLL, I. R., 1971. Systematic and biogeographic relationships of some Dugesia species (Tricladida, Paludicola) from Central and South America. Am. Mus. Novit., 2472: 1-25. 
Bold, W. A. VAN DEN, 1958. Distribution of freshwater ostracodes in Trinidad. Micropaleontology, 4 (1): 71-74.

Botosaneanu, L., 1979. The caddis-flies (Trichoptera) of Cuba and of Isla de Pinos: a synthesis. Stud. Fauna Curaçao, 59 (185): 33-62.

Brady, G. S., 1902. On new or imperfectly-known Ostracoda, chiefly from a collection in the Zoological Museum, Copenhagen. Trans. zool. Soc. London, 16 (4): 179-210, pls. XXI-XXV.

BreHM, V., 1949. Datos para la fauna de agua dulce de Cuba. Publnes. Inst. Biol. apl. Barcelona, 5: 95-112.

Broodbakker, N. W., 1982. The genus Heterocypris (Crustacea, Ostracoda) in the West Indies. Part I. Taxonomic characters. Bijdr. Dierk., 52 (2): 207-227.

- , 1983a. The genus Heterocypris (Crustacea, Ostracoda) in the West Indies. Part II. Carapace length, ecology and zoogeography. Bijdr. Dierk., 53 (1): 115-134.

-, $1983 \mathrm{~b}$. The genus Hemicypris (Crustacea, Ostracoda) in the West Indies. Bijdr. Dierk., 53 (1): 135-157.

- $1983 \mathrm{c}$. The subfamily Candoninae (Crustacea, Ostracoda) in the West Indies. Bijdr. Dierk., 53 (2): 287-326.

-, $1983 \mathrm{~d}$. The genus Strandesia and other Cypricercini (Crustacea, Ostracoda) in the West Indies. Part I. Taxonomy. Bijdr. Dierk., 53 (2): 327-363.

- , 1984a. The genus Strandesia and other Cypricercini (Crustacea, Ostracoda) in the West Indies. Part II. Carapace length, ecology, and distribution of two Strandesia species. Bijdr. Dierk., 54 (1): 1-14.

,$-- 1984 b$. The genus Tanycypris (Crustacea, Ostracoda) in the West Indies. Bijdr. Dierk., 54 (1): 15-24.

Broodbakker, N. W. \& D. L. Danielopol, 1982. The chaetotaxy of Cypridacea (Crustacea, Ostracoda) limbs: proposals for a descriptive model. Bijdr. Dierk., 52 (2): 103-120.

Brown, F. M., 1978. The origins of the West Indian butterfly fauna. In: F. B. GiLl ed., Zoogeography in the Caribbean. The 1975 Leidy Medal Symposium. Spec. Publs. Acad. nat. Sci. Philad., 13: 5-29.

Crolzat, L., 1976. Biogeografia analitica y sintetica ("panbiogeografia") de Las Americas. Boln. Acad. Cienc. fis., Caracas, 35 (103-106): 1-890.

Danielopol, D. L., 1972. Sur la présence de Thaumatocypris orghidani n. sp. (Ostracoda-Myodocopida) dans une grotte de Cuba. C. r. hebd. Séanc. Acad. Sci., Paris, (D) 247: 1390-1393.

-—, 1978. Über Herkunft und Morphologie der Süsswasser-hypogäischen Candoninae (Crustacea, Ostracoda). Sber. öst. Akad. Wiss., (Abt. I) 187 (1-5): 1-162.

-, 1981 . Distribution of ostracods in the groundwater of the north western coast of Euboea (Greece). Int. J. Speleol., 11: 91-103.

_-, 1982. Deux espèces hypogées du genre Candonopsis
(Ostracoda, Candoninae) du sud de la France et de Cuba. Vie Milieu, 30 (3-4) "1980”: 315-323.

Darlington, P. J. Jr., 1957. Zoogeography: the geographical distribution of animals: 1-675 (John Wiley \& Sons, New York).

DeckKer, P. DE, 1977. The distribution of the 'giant' ostracods (family: Cyprididae Baird, 1845) endemic to Australia. In: H. Löffler D. L. Danielopol eds., Aspects of ecology and zoogeography of recent and fossil Ostracoda: 1-521 (Junk Publishers, The Hague).

Delorme, L. D. \& D. Donald, 1969. Torpidity of freshwater ostracodes. Can. J. Zool., 47 (5): 997-999, pl. I.

Dickinson, W. R. \& P. J. Coney, 1980. Plate tectonic constraints on the origin of the Gulf of Mexico. In: $R$. H. Pilger Jr. ed., The origin of the Gulf of Mexico and the early opening of the central North Atlantic Ocean. Proceedings of a symposium at L.S.U., Baton Rouge, Louisiana: 27-36.

Fryer, G., 1953. Notes on certain freshwater crustaceans. Naturalist, Hull, 846: 101-109.

Furros, N. C., 1936. On the Ostracoda from the cenotes of Yucatan and vicinity. Publs. Carnegie Instn., 457: 89-115.

- - 1938. A new species of Cypridopsis from Yucatan. Publs. Carnegie Instn., 491: 155-157.

Harrison, A. D. \& J. J. Rankin, 1976. Hydrobiological studies of eastern Lesser Antillean Islands, II. St. Vincent: Freshwater fauna - its distribution, tropical river zonation and biogeography. Arch. Hydrobiol., Suppl. 50: 275-311.

HartmanN, G., 1974. Zum gegenwärtigen Stand der Erforschung der Ostracoden interstitieller Systeme. Annls. Spéléol., 28 (3) “1973”': 417-427.

Hedges, S. B., 1982. Caribbean biogeography: implications of recent plate tectonic studies. Syst. Zool., 31 (4): 518-522.

Hummelinck, P. WagenaAR, 1940a. General information. Stud. Fauna Curaçao, 1 (1): 1-58.

-, $1940 \mathrm{~b}$. Descriptions of the localities. Stud. Fauna Curaçao, 2 (4): 1-42.

-, 1953. Description of new localities. Stud. Fauna Curaçao, 4 (17): 1-108.

- - 1981. Land and fresh-water localities. Stud. Fauna Curaçao, 63 (192): 1-133, pls. I-IL.

Keyser, D., 1975. Ostracoden aus den Mangrovegebieten von Südwest-Florida (Crustacea: Ostracoda, Podocopa). Abh. Verh. naturw. Ver. Hamburg, (N.F.) 18/19: 255-290, pls. XX-XXII.

KLIE, W., 1933. Zoologische Ergebnisse einer Reise nach Bonaire, Curaçao und Aruba im Jahre 1930. No. 5. Süss- und Brackwasser-Ostracoden von Bonaire, Curaçao und Aruba. Zool. Jb., (Syst.) 64: 369-390. , 1940. Süsswasserostracoden aus Nordostbrasilien. VI. Cyprinae mit geisselförmiger Furka. Zool. Anz., 130: 59-73.

Kornicker, L. S. \& I. G. Sohn, 1971. Viability of ostra- 
code eggs egested by fish and effect of digestive fluids on ostracode shells - Ecologic and paleoecologic implications. In: H. J. Oertli ed., Colloquium on the paleoecology of ostracodes. Bull. Cent. Rech. Pau, Suppl. 5: 125-135.

Kotzian, S. C. B., 1974. New fresh-water ostracodes of the genus Chlamydotheca from Brazil. Ecology, geographic distribution and stratigraphical position. Anais Acad. bras. Ciênc., 46 (3/4): 423-467.

MacArthur, R. H. E. O. Wilson, 1967. The theory of island biogeography: i-xi, 1-203 (Princeton Univ. Press, Princeton, N.J.).

McKenzie, K. G., 1971. Palaeozoogeography of freshwater Ostracoda. In: H. J. Oertli ed., Colloquium on the paleoecology of ostracodes. Bull. Cent. Rech. Pau, Suppl. 5: 207-237.

McLay, C. L., 1978. Comparative observations on the ecology of four species of ostracods living in a temporary freshwater puddle. Can. J. Zool., 56 (4): 663-675.

Margalef, R., 1961. La vida en los charcos de agua dulce de Nueva Esparta (Venezuela). Mems. Soc. Cienc. nat. La Salle, 21 (59): 75-110.

Morkhoven, F. P. C. M. van, 1962. Post Palaeozoic Ostracoda: their morphology, taxonomy and economic use, 1: 1-204 (Elsevier, Amsterdam).

Müller, P., 1973. The dispersal centres of terrestrial vertebrates in the Neotropical realm. A study in the evolution of the Neotropical biota and its native landscapes: i-vi, 1-244 (Junk, The Hague).

Nelson, G. \& N. Platnick, 1981. Systematics and biogeography: cladistics and vicariance: 1-567 (Columbia University Press, New York).

Nelson, G. \& D. E. Rosen eds., 1981. Vicariance biogeography: a critique: 1-593 (Columbia University Press, New York).

Petkovski, T. K., 1964. Bemerkenswerte Entomostraken aus Jugoslavien. Acta Mus. maced. Sci. nat., 9 (7): 147-181.

Pregill, G. K. S. L. Olson, 1981. Zoogeography of West Indian vertebrates in relation to Pleistocene climatic cycles. A. Rev. Ecol. Syst., 12: 75-98.

Proctor, V. W., 1964. Viability of crustacean eggs recovered from ducks. Ecology, 45: 656-658.

Proctor, V. W. \& C. R. Malone, 1965. Further evidence of the passive dispersal of small aquatic organisms via the internal tract of birds. Ecology, 46: 728-729.

Rosen, D. E., 1976. A vicariance model of Caribbean biogeography. Syst. Zool., 24: 431-464.

Ross, H. H., 1967. The evolution and past dispersal of the Trichoptera. A. Rev. Ent., 12: 169-206.

SAether, O. A., 1981. Orthocladiinae (Diptera: Chironomidae) from the British West Indies, with descriptions of Antillocladius n. gen., Lipurometriocnemus n. gen., Compterosmittia n. gen. and Diplosmittia n. gen. Entomologica scand., Suppl. 16: 1-46.

SandBerg, P. A.; 1964. The ostracod genus Cyprideis in the Americas. Stockh. Contr. Geol., 12: 1-178.

SARs, G. O., 1889. On some freshwater Ostracoda and Copepoda from dried Australian mud. Forh. VidenskSelsk. Krist., 8: 1-79, pls. I-VIII.

-, 1901 . Contributions to the knowledge of the freshwater Entomostraca of South America, as shown by artificial hatching from dried material, Part II. Arch. Math. Naturv., 24 (1): 1-52.

Sharpe, R. W., 1910. On some Ostracoda, mostly new, in the collection of the United States National Museum. Proc. U. S. natn. Mus., 38: 335-341.

Sohn, I. G. \& L. S. Kornicker, 1973. Morphology of Cypretta kawatai Sohn and Kornicker, 1972 (Crustacea, Ostracoda), with a discussion of the genus. Smithson. Contr. Zool., 141: 1-28.

- $~-\ldots, 1979$. Viability of freeze-dried eggs of the freshwater Heterocypris incongruens: 1-4. In: $N$. Krstić ed., Taxonomy, biostratigraphy and distribution of ostracodes. Proceedings of the. 7th international symposium on ostracodes: 1-272 (Serbian Geological Society, Belgrade).

Sokal, R. R. F. J. Rohlf, 1981. Biometry, 2nd edition: 1-859 (W. H. Freeman \& Co., San Francisco).

Srock, J. H., 1977. The taxonomy and zoogeography of the hadziid Amphipoda, with emphasis on the West Indian taxa. Stud. Fauna Curaçao, 55 (117): 1-129.

-_, 1979. Amsterdam Expeditions to the West Indian Islands, Report 4. Station list. Verslagen technische Gegevens Inst. taxon. Zoöl. (Zoöl. Mus.) Univ. Amsterdam, 20: 1-78.

-, 1980 . Regression model evolution as exemplified by the genus Pseudoniphargus (Amphipoda). Bijdr. Dierk., 50 (1): 105-144.

-, 1981 . L'Origine géologique des îles des Indes Occidentales en relation avec la dispersion de quelques Malacostracés stygobiontes. Géobios (Lyon), 14 (2): 219-227.

- $-1983 a$. Predation as a factor influencing the occurrence and distribution of small Crustacea in West Indian groundwaters. Bijdr. Dierk., 53 (2): 233-243.

-, 1983b. The stygobiont Amphipoda of Jamaica. Bijdr. Dierk., 53 (2): 267-286.

Triebel, E., 1961. Süsswasser-Ostracoden von den Karibischen Inseln: 1. Cypridini. Senckenberg. biol., 42: 51-74, pls. 6-17.

Inseln: 2. Xenocypris n. g. Senckenberg. biol., 43: 47-63.

Victor, R. C. H. Fernando, 1981. Freshwater ostracods (Crustacea: Ostracoda) of the genus Cypretta Vavra, 1895 from Malaysia, Indonesia and the Philippines. Int. Revue ges. Hydrobiol., 66 (3): 415-433. 